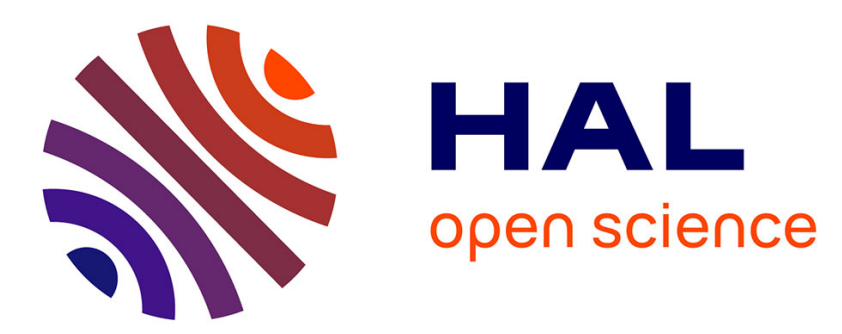

\title{
The physicochemical properties of membranes correlate with the NADPH oxidase activity
}

Hager Souabni, Frank Wien, Tania Bizouarn, Chantal Houée-Levin, Matthieu

M. Refregiers, Laura Baciou

\section{- To cite this version:}

Hager Souabni, Frank Wien, Tania Bizouarn, Chantal Houée-Levin, Matthieu M. Refregiers, et al.. The physicochemical properties of membranes correlate with the NADPH oxidase activity. Biochimica et Biophysica Acta (BBA) - General Subjects, 2017, 1861 (1, Part B), pp.3520-3530. 10.1016/j.bbagen.2016.06.028 . hal-01566812

\section{HAL Id: hal-01566812 https://hal.science/hal-01566812}

Submitted on 21 Jul 2017

HAL is a multi-disciplinary open access archive for the deposit and dissemination of scientific research documents, whether they are published or not. The documents may come from teaching and research institutions in France or abroad, or from public or private research centers.
L'archive ouverte pluridisciplinaire HAL, est destinée au dépôt et à la diffusion de documents scientifiques de niveau recherche, publiés ou non, émanant des établissements d'enseignement et de recherche français ou étrangers, des laboratoires publics ou privés. 
The physicochemical properties of membranes correlate with the NADPH oxidase activity

Hager Souabni ${ }^{1,3}$, Frank Wien ${ }^{2}$, Tania Bizouarn ${ }^{1}$, Chantal Houée-Levin ${ }^{1}$, Matthieu Réfrégiers ${ }^{2}$, Laura Baciou $^{1 *}$

${ }^{1}$ Laboratoire de Chimie Physique UMR 8000, Univ. Paris-Sud, CNRS, Université Paris Saclay, 91405 Orsay Cedex France.

${ }^{2}$ Synchrotron SOLEIL, Campus Paris-Saclay, 91192 Gif-sur-Yvette Cedex, France

${ }^{3}$ Present address: Institut de Biologie Physico-Chimique, Laboratoire de Biologie Physicochimique des Protéines Membranaires, CNRS, UMR7099, 75005 Paris, France;

\section{${ }^{*}$ Corresponding author}

Laboratory of Physical Chemistry, UMR8000, Bat. 350, University of Paris Sud, 91405 Orsay, France. Phone : +33 169157711 Fax number: +33 16915 6188; laura.baciou@u-psud.fr 


\begin{abstract}
(250 words)
Background: Phagocytes kill ingested microbes by exposure them to high concentrations of toxic reactive species generated by NADPH-oxidases. This membrane-bound electrontransferring enzyme is tightly regulated by cellular signalling cascades. So far, molecular and biophysical studies of the NADPH-oxidase were performed over limited temperatures ranges, which weaken our understanding of immune response or inflammatory events. In this work, we have inspected the influence of temperature and lipid membrane properties on the NADPH-oxidase activity using a system free of cell complexity.
\end{abstract}

Methods: We have extended the experimental conditions of the accepted model for NADPHoxidase activity, the so-called cell-free assay, to a large temperature range $\left(10-40{ }^{\circ} \mathrm{C}\right)$ using different membrane compositions (subcellular compartments or liposomes).

Results: A remarkable increase of superoxide production rate was observed with rising temperature. Synchrotron radiation circular dichroism data showed that this is not correlated with protein secondary structure changes. When lipid bilayers are in fluid phase, Arrhenius plots of the oxidase activity showed linear relationships with small activation energy ( $\mathrm{E} a$ ), while when in solid phase, high $\mathrm{E} a$ was found. The sterol content modulates kinetic and thermodynamic parameters.

Conclusion: High temperature promotes the rate of superoxide production. The key element of this enhancement is related to membrane properties such as thickness and viscosity and not to protein structural changes. Membrane viscosity that can be driven by sterols is a paramount parameter of $\mathrm{E} a$ of NADPH oxidase activity. The membrane bilayer state modulated by its sterols content may be considered locally as an enzyme regulator.

\title{
Keywords:
}

NADPH oxidase (Nox), recombinant cell free assay, lipids, membrane proteins, sterols, temperature dependence, SRCD, phase transition

\begin{abstract}
Abbreviations
The abbreviations used are: $r \mathrm{Cyt} b_{558}$, recombinant cytochrome $b_{558}$; ER, membrane of endoplasmic reticulum; PM, plasma membrane; PL, proteoliposome; AA, arachidonic acid; DMSO, dimethylsulphoxide; SOD, Superoxide dismustase; Nox, NADPH oxidase; Cytc, cytochrome $c$; PMSF, phenylmethanesulfonyl fluoride; $\mathrm{M} \beta \mathrm{CD}$, methyl- $\beta$-cyclodextrin; DDM, n-Dodecyl $\beta$-D-Maltoside; DOPC, 1,2-dioleoyl-sn-glycero-3-phosphocholine; DMPC, 1,2dimyristoyl-sn-glycero-3-phosphocholine; Ea, Arrhenius activation energy; NADPH, reduced $\beta$-nicotinamide adenine dinucleotide phosphate; DTT, dithiothreitol; SRCD, Synchrotron radiation circular dichroism; $\mathrm{T}_{\mathrm{m}}$, phase transition temperature.
\end{abstract}




\section{Highlights}

- High temperatures promote high production rates of superoxide anions

- Production of reactive oxygen species is closely related to bilayer composition and membrane thickness

- Oxidase activation energy is correlated to the bilayer fluidity

- Sterols are negative regulators of NADPH oxidase activity 


\section{Introduction}

Inflammation is a normal host defense mechanism which protects the host from infection through pathogen killing. This inflammatory response is well regulated in order to protect the host against excessive damage and is accompanied by an increase in body temperature (hyperthermia). Normal body temperature generally does not exceed $37.9{ }^{\circ} \mathrm{C}$. Many causes of fever can be encountered (tumor, rheumatic disorders, granulomatous diseases ...) but infections are the most frequent causes of a brief fever which corresponds to an elevation of the body temperature above $38.2{ }^{\circ} \mathrm{C}$. Neutrophils are one of the first phagocyte cells which are sought to fight pathogens by using its efficient enzymatic and killing machinery, which include the NADPH oxidase complex. In phagocyte cells, the NADPH oxidase complex converts the chemical reducing equivalent of NADPH into superoxide anions $\left(\mathrm{O}_{2}{ }^{-}\right)$in the intraphagosomal space. The superoxide anion is the precursor of the so-called Reactive Oxygen Species (ROS) which serve as microbicide weapons. The physiological importance of the phagocyte NADPH oxidase is evidenced by an immunodeficiency disease called chronic granulomatous disease (CGD), in which defective microorganism killing entails recurrent and severe infections (reviewed in [1]). Studies over the last decade revealed homologs of phagocyte NADPH oxidases forming the NOX family [2, 3], which enlarged considerably the number of its physiological functions (inflammatory response, post-translational proteins processing, inter- and intra-cellular signaling, regulation of endothelial function, regulation of gene expression and cell differentiation...).

The phagocyte NADPH oxidase complex is a multicomponent enzyme constituted of the membrane flavocytochrome $b_{558}\left(\mathrm{Cyt} b_{558}\right)$ which is a heterodimer of Nox2 (also referred as gp91 $1^{\text {phox }}$ ) and $\mathrm{p} 22^{\text {phox }}$, and at least four cytosolic proteins, $\mathrm{p} 47^{\text {phox }}, \mathrm{p} 67^{\text {phox }}, \mathrm{p} 40^{\text {phox }}$ and GTPbinding protein Rac1/2 (reviewed in $[4,5]$ ). Localized in the Nox2 protein, one flavin and two hemes serve as redox intermediates for transmembrane electron transfers from NADPH to molecular oxygens in order to generate $\mathrm{O}_{2}{ }^{\circ}$. When phagocytes are exposed to pathogens or inflammatory mediators, the NADPH oxidase is activated. Its activation encompasses the assembly of the cytosolic proteins to the Cyt $b_{558}$ catalytic core. This assembly is finely controlled spatially and temporally by cell signaling processes. This spatio-temporal regulation, which remains unclear, can be different depending on the cellular localization of the enzyme. The primordial elements of this machinery are lipid-protein and protein-protein interactions (reviewed in [5-8]). Several events are triggered by phosphorylation events [9- 
14], others by secondary messengers such as cis-arachidonic acid [15-18]. Recently, we have reported that, in vitro, the substitution of cis- by trans-arachidonic acid (currently observed when fatty acids are isomerized by free radicals) inhibits NADPH oxidase activity [19].

Although the importance of the lipid metabolism was evidenced, the regulator role of the lipid membrane properties remains unclear. Neutrophil plasma membranes are mainly composed by phospholipids, phosphatidylcholine (40-50\%) being the most abundant phospholipid in neutrophils (PE, PI and PS being about $30 \%, 5-9 \%$ and $10 \%$, respectively) [20]. Also phospholipid composition changes during neutrophil activation and phagocyte formation have been shown to be important modulators of NADPH oxidase activity by helping and maintaining the recruitment of the cytosolic proteins to the membrane [21-24]. Additionally in various cell types, NADPH oxidase has been identified in caveolae and lipid rafts [25]. Raft domains adopt a liquid ordered phase formed by tightly packed cholesterol and sphingolipids. These microdomains are involved in phagocytosis [26]. It has been reported that disruption of lipid rafts resulted in the downregulation of NADPH oxidase subunits in breast cancer cells [27] and in a compromised superoxide production [28], while lipid rafts have also been shown to maintain NADPH oxidase in an inactive state [29]. We could also observe that sterolenriched membranes decrease the rate of superoxide anion produced by recombinant NADPH oxidase [30,31]. This might be explained by different types of lipid raft redox platforms as described in [32]. Insofar, as lipid composition is also of importance in the epidemiology of important human diseases such as atherosclerosis, infectious diseases, Alzheimer's disease and cancer in which the role of NADPH oxidase has been demonstrated, it is particularly important to identify the correlation between lipid environment and NADPH oxidase activity.

The aim of the present in vitro study was to investigate the involvement of membrane composition and its physical state in the regulation of NADPH oxidase superoxide production. For this purpose the NADPH oxidase was reconstituted in the valuable recombinant cell-free assay system using the recombinant $\mathrm{Cyt} b_{558}$ heterologous expressed in yeast Pichia pastoris cells [33]. In this paper, its activity was explored in function of the membrane lipid composition and physic state. Both were controlled chemically and thermodynamically in order to learn if these two events were linked. The aim was to demonstrate an eventual direct relationship between superoxide production rates and membrane properties. 


\section{Materials and methods}

\subsection{Materials}

Superoxide dismutase (SOD), cytochrome c (Cytc), phenylmethanesulfonyl fluoride (PMSF), dodecyl maltoside (DDM), methyl- $\beta$-cyclodextrin $(\mathrm{M} \beta \mathrm{CD})$, ergosterol, cholesterol and arachidonic acid were purchased from Sigma (Saint Quentin Fallavier, France). Reduced $\beta$ nicotinamide adenine dinucleotide phosphate (NADPH) was purchased from Acros Organics (Thermo Fisher Scientific).

\subsection{Heterologous cytochrome $b_{558}$ expression in Pichia pastoris}

Recombinant P. pastoris SMD1168 strain (his4 pep4) transformed with the pAO81 plasmid containing the entire expression cassette with the gp91 ${ }^{\text {phox }}$ and $\mathrm{p} 22^{\text {phox }}$ sequences described elsewhere [33] were grown overnight in BMGY media (1\% yeast extract, $2 \%$ peptone, 100 $\mathrm{mM}$ potassium phosphate, $\mathrm{pH} 6.0,1.34 \%$ yeast nitrogen base, $4 \times 10^{-5} \%$ biotin, $1 \%$ glycerol) supplemented with $0.05 \mathrm{mg} / \mathrm{ml}$ ampicillin. Cells were pelleted by centrifugation $(10 \mathrm{~min}$ at $550 \mathrm{x} \mathrm{g}$ ) and resuspended in BMMY medium (similar to BMGY but glycerol was substituted by $1 \%$ methanol) supplemented with ampicillin at an $\mathrm{OD}_{600 \mathrm{~nm}}=1.0$. Cells were grown in baffled culture flasks at $30{ }^{\circ} \mathrm{C}$ with shaking at $200 \mathrm{rpm}$. Methanol $(1 \%$, v/v final concentration) was supplied every $24 \mathrm{~h}$ to maintain the expression induction. $72 \mathrm{~h}$ after induction, cells were harvested by centrifugation and stored at $-80{ }^{\circ} \mathrm{C}$.

\subsection{Yeast subcellular Fractioning}

P. pastoris membrane fraction was obtained as previously described [30]. Briefly, cell pellets from a $72 \mathrm{~h}$ yeast culture were thawed and resuspended in cell breaking buffer containing $50 \mathrm{mM}$ sodium phosphate, pH 7.4, $1 \mathrm{mM}$ PMSF, $1 \mathrm{mM}$ EDTA and 5\% glycerol. All steps were carried out at $4{ }^{\circ} \mathrm{C}$. Cells were lysed by alternating $30 \mathrm{~s}$ vortexing followed by cooling period (1 $\min 30 \mathrm{~s}$ ) on ice bath during $20 \mathrm{~min}$. The lysate was clarified by centrifugation at $500 \mathrm{x} \mathrm{g}$ for $10 \mathrm{~min}$ at $4{ }^{\circ} \mathrm{C}$. The total membrane fractions were collected by centrifugation at $130,000 \mathrm{x}$ g for $90 \mathrm{~min}$ and resuspended in $50 \mathrm{mM}$ Tris/ $\mathrm{HCl} \mathrm{pH} 8.0,120$ $\mathrm{mM} \mathrm{NaCl}, 10 \%$ glycerol, $1 \mathrm{mM}$ PMSF. After membrane fractioning on sucrose gradient, the membrane fraction was resuspended in STE $10 \%$ buffer $(20 \mathrm{mM}$ Tris/HCl pH 7.4, $1 \mathrm{mM}$ EDTA and $10 \%$ sucrose). The protein concentration of each sample was estimated using the Pierce Bicinchoninic acid protein assay with bovine serum albumin as standard. About 6 $\mathrm{mg} / \mathrm{ml}$ of total membrane proteins were usually obtained. The separation of the endoplasmic reticulum (ER) and plasma membranes (PM) were performed onto a discontinuous sucrose 
gradient (20-60\% sucrose) as described in [30]. For further analysis, the ER and PM fractions were pelleted at 30,000 $\mathrm{x}$ g and resuspended in $1 \mathrm{mM}$ EDTA, 30\% sucrose, $20 \mathrm{mM}$ Tris/ $\mathrm{HCl}$ $\mathrm{pH} 8.0$ and stored at $-20{ }^{\circ} \mathrm{C}$.

\subsection{Ergosterol extraction and insertion}

The removal of ergosterol from $P$. pastoris plasma membranes was obtained as described in [30]. Briefly, the membrane fractions (6 $\mathrm{mg}$ of protein $/ \mathrm{ml}$ ) were incubated with $20 \mathrm{mM}$ methyl- $\beta$-cyclodextrin $(\mathrm{M} \beta \mathrm{CD})$ at $25{ }^{\circ} \mathrm{C}$ in a roller shaker for $30 \mathrm{~min}$. After centrifugation at $130,000 \mathrm{x}$ g for $90 \mathrm{~min}$, the membrane pellet was resuspended with the same buffer as mentioned above (1 mM EDTA, 30\% sucrose, $20 \mathrm{mM}$ Tris/HCl $\mathrm{pH} 8.0)$ and stored at $-20{ }^{\circ} \mathrm{C}$.

The insertion of sterols into ER membranes was performed by incubation of the membranes ( $2 \mathrm{mg} / \mathrm{ml}$ of total membrane protein) under low agitation during $30 \mathrm{~min}$ at $25^{\circ} \mathrm{C}$ with $20 \mu \mathrm{M}$ of ergosterol or cholesterol, so that the ergosterol/total membrane proteins ratio was kept equal to 0.45 (close to the value described in the literature for plasma membranes [34]).

\subsection{Purification of the recombinant Cytb558}

The recombinant $r \mathrm{Cyt} b_{558}$ was solubilized from the total yeast membrane fraction by the nonionic detergent, $\mathrm{n}$-Dodecyl $\beta$-D-maltoside (DDM). Membrane solubilization was achieved at detergent/protein ratio of $3(\mathrm{w} / \mathrm{w})$ and the mixed solution was incubated at room temperature for 1 hour with gentle agitation. The solubilized $r \mathrm{Cyt} b_{558}$ was clarified by centrifugation at $130,000 \mathrm{x} \mathrm{g}$ for $90 \mathrm{~min}$. The solubilized protein was first loaded onto Heparine Sepharose column equilibrated with $20 \mathrm{mM}$ Tris $\mathrm{HCl}, \mathrm{pH} 8.0,1 \mathrm{mM}$ EDTA, $0.025 \%$ DDM. The fractions containing the recombinant cytochrome $b_{558}$ were eluted between $0.3-0.4 \mathrm{M} \mathrm{NaCl}$ (in $20 \mathrm{mM}$ Tris- $\mathrm{HCl}, \mathrm{pH}$ 8.0, $1 \mathrm{mM}$ EDTA, $0.025 \%$ DDM). The pooled protein was concentrated using Vivaspin filters and further separated using Superdex 200 gel filtration column equilibrated with $20 \mathrm{mM}$ Tris $\mathrm{HCl}, \mathrm{pH} 8.0,120 \mathrm{mM} \mathrm{NaCl}$, and $0.025 \%$ DDM. All purification steps were achieved using an automated Äkta chromatography system (GE Healthcare, Velizy Villacoublay, France). The amount of purified $r$ Cyt $b_{558}$ was determined from the dithionite-reduced minus oxidized difference spectra recorded between 400 and 600 nm on a double beam Uvikon 943 spectrophotometer (Kontron Instruments, Milan, Italy). This amount was calculated from the absorbance difference between the peak at $427 \mathrm{~nm}$ and the hollow at $411 \mathrm{~nm}$ using a millimolar extinction coefficient of $\Delta \varepsilon_{427-411}=200 \mathrm{mM}^{-1}$ $\mathrm{cm}^{-1}[35]$. 


\subsection{Relipidation of rCytb558}

A stock solution of 1,2-dioleoyl-sn-glycero-3-phosphocholine (DOPC) or 1,2-dimyristoyl-snglycero-3-phosphocholine (DMPC) from Avanti Polar Lipids was diluted in phosphate buffer solution (PBS, pH 7.5) at a concentration of $50 \mathrm{mg} / \mathrm{mL}$, then lipid suspension was shaken in a vortex, and then sonicated. The DDM-solubilized $r$ Cyt $b_{558}$ was added to liposomes with a lipid/protein ration of 5:1 $(\mathrm{w} / \mathrm{w})$. The resulting micellar protein/lipid/detergent mixture was stirred for $30 \mathrm{~min}$ before addition of Bio-Beads SM2 (Biorad, Life Science, Marnes-laCoquette, France) to remove the detergent [36]. Vesicles formation was followed by absorbance at $400 \mathrm{~nm}$. Bio-Beads were subsequently removed and the solution containing the proteoliposomes (PL) was kept at $-20^{\circ} \mathrm{C}$, until use. The DMPC and DOPC PLs were prepared using the same methods, except that the liposome preparation, the reconstitution with the $r$ Cytb558 and the elimination of the detergent (DDM) were done at $27^{\circ} \mathrm{C}$ for DMPC and $21^{\circ} \mathrm{C}$ for DOPC, i. e. above the lipid phase transition temperature (Tm).

\subsection{Cell-free NADPH oxidase activity assay}

Enzymatic activity was assayed with the Uvikon 943 spectrophotometer (Kontron Instruments, Milan, Italy). Superoxide anion formation rate was determined from a kinetic assay of the reduction of cytochrome $\mathrm{c}(\mathrm{Cyt} c)$ as described before [37]. The reaction mixture contained 1-5 $\mathrm{nM}$ of $\mathrm{Cyt} b_{558}$ in yeast membrane fractions (endoplasmic reticulum or plasma membrane) or in proteoliposomes and $200 \mathrm{nM}$ of each purified recombinant cytosolic factors (bovine $\mathrm{p} 67^{\text {phox }}, \mathrm{p} 47^{\text {phox }}$, and human RacQ61L). The mixture was incubated for 5 min in the presence of optimal arachidonic acid concentration at a temperature ranging between 10 and $40{ }^{\circ} \mathrm{C}$ prior to addition of $50 \mu \mathrm{M}$ Cytc and initiation of the reaction by the addition of $500 \mu \mathrm{M}$ NADPH. Cytosolic proteins were prepared as described in [38], except that the inductions of $\mathrm{p} 67^{\text {phox }}$ and $\mathrm{p} 47^{\text {phox }}$ expression were done at $25^{\circ} \mathrm{C}$. The final volume of the reaction was 500 $\mu 1$ adjusted with the activity assay buffer containing $20 \mathrm{mM}$ Tris/ $\mathrm{HCl} \mathrm{pH} 8,1 \mathrm{mM}$ EDTA and $120 \mathrm{mM} \mathrm{NaCl}$. The linear portion of the kinetic curves followed at $550 \mathrm{~nm}$, corresponding to Cytc reduction, was used to determine the maximal rates of $\mathrm{O}_{2}{ }^{--}$production. The amount of superoxide was calculated using a molar absorption coefficient $(\Delta \varepsilon$ of the reduced minus oxidized Cytc) of $21 \mathrm{mM}^{-1} \cdot \mathrm{cm}^{-1}$. The rate was expressed in function of of $r$ Cyt $b_{558}$ concentration to give a specific activity $\left(k_{\mathrm{cat}}\right)$. For each condition, three independent experiments were performed. The points indicated on the figures are the mean \pm SD of the three rates determined from each experiment. To test the specificity of the Cyt $c$ assay for $\mathrm{O}_{2}^{-\bullet}$ release, controls were performed in the presence of $50 \mu \mathrm{g} / \mathrm{ml}$ bovine erythrocyte superoxide 
dismutase (SOD). Incubation of the mixture reaction was kept at the same temperature as the following experiment in the Peltier-mediated temperature controlled Uvikon optical cell.

\subsection{Arrhenius plots of NADPH oxidase activities}

The temperature dependences of the NADPH oxidase activities were analyzed in term of thermally activated processes by calculating Arrhenius plots. To build these plots, since the concentration of NADPH was 10 times larger than its $\mathrm{K}_{\mathrm{m}}$ [30], we considered that the reaction was zero-order with respect to NADPH. The rate constants at each temperature $k_{\text {cat }}$, were therefore taken equal to the initial rates of formation of $\mathrm{O}_{2}{ }^{--}$and adjusted with $r \mathrm{Cyt} b_{558}$ concentration and expressed in moles $\mathrm{O}_{2}{ }^{-} \cdot \mathrm{s}^{-1} \cdot \mathrm{mol} \mathrm{Cyt} b_{558}{ }^{-1}$. According to the linear expression of the Arrhenius equation, $\ln k_{\text {cat }}$ was plotted against the reciprocal of the absolute assay temperature in Kelvin $(1 / \mathrm{T})$ :

$$
\begin{aligned}
k_{\text {cat }}\left(\mathrm{s}^{-1}\right)=\mathrm{A} \cdot \mathrm{e}^{-\mathrm{E} a / \mathrm{RT}} & \text { (equation 1) } \\
\ln k_{\mathrm{cat}}=\ln \mathrm{A}-\mathrm{E} a / \mathrm{RT} & \text { (equation 2) }
\end{aligned}
$$

In these equations, $\mathrm{A}$ is the pre-exponential factor of the rate constant, $\mathrm{E} a$ is the activation energy and $\mathrm{R}$ is the gas constant $\left(8.314 \mathrm{~J} \cdot \mathrm{mol}^{-1} \cdot \mathrm{K}^{-1}\right)$. The activation energy (Ea) was calculated from the slope of each straight line. According to the units employed, the activation energies were then expressed in $\mathrm{kJ} / \mathrm{mol}$.

\subsection{Circular dichroism spectroscopy}

To maintain the ionic strength (anions, such as fluoride, maintain ionic strength and preserve the structure of recombinant proteins), purified recombinant proteins were dialyzed overnight against $100 \mathrm{mM} \mathrm{NaF}$ and buffered with a low concentration of sodium phosphate buffer (10 $\mathrm{mM}$ sodium phosphate, $\mathrm{pH}$ 7.4) using Slide-A-lyzer mini dialysis units [MW $30 \mathrm{~K}$ cutoff] (Pierce). For $r \mathrm{Cyt} b_{558}$, the buffer was supplemented with detergent at a concentration of 0.025 \% DDM. The dialysate buffer was kept for SRCD baseline. Prior to data collection, the samples were briefly centrifuged at $10000 \mathrm{x}$ g to remove any protein aggregates.

Synchrotron radiation circular dichroism (SRCD) spectra were collected on the DISCO beamline at the synchrotron SOLEIL, Gif-sur-Yvette, France [39, 40]. All spectra were calibrated for wavelengths and amplitudes with camphor sulphonic acid (CSA). Samples were loaded in $\mathrm{CaF}_{2}$ cells using $25 \mu \mathrm{l}$ volumes and optical pathlengths of 33 and $50 \mu \mathrm{m}$ depending on the protein concentrations (between 14-40 $\mu \mathrm{M}$ ) [41]. Spectra were measured from 280 to 
$170 \mathrm{~nm}$, using the mid-height of the HT (high tension) as cut-off at $700 \mathrm{~V}$. Three consecutive scans were recorded and averaged for the samples and the baseline. The averaged baseline was subtracted from the averaged sample spectra and smoothed with 7 points using the Savitsky-Golay algorithm. The temperature scans were performed from 25 to $90{ }^{\circ} \mathrm{C}$ with steps of $5{ }^{\circ} \mathrm{C}$ and reversibility was verified by heating and cooling. The conformation changes with temperature were described as the following equilibrium:

$$
r \text { Cyt } b_{558} \text { (folded) } \stackrel{K}{\leftrightarrow} r \text { Cyt } b_{558} \text { (unfolded) }
$$

The temperature dependence of the equilibrium constant, K, was analyzed using the Van't Hoff equation

$$
\frac{\square \square \square \square(\square)}{\square \square}=\frac{\Delta_{\square} \square^{\circ}}{\square \square^{2}}
$$

Assuming that the enthalpy variation is constant in the temperature range, this expression leads to:

$$
\ln (\square(\square))=-\frac{\Delta \square \square^{\circ}}{\square \square}+\frac{\Delta \square \square^{\circ}}{\square}
$$

In this expression, $\Delta_{\mathrm{r}} \mathrm{H}^{\circ}$ and $\Delta_{\mathrm{r}} \mathrm{S}^{\circ}$ are the enthalpy and the entropy variations related to the equilibrium (equation 3) respectively.

Protein concentrations were reassessed from their absorbance at $280 \mathrm{~nm}$ and their calculated absorption coefficient (Expasy ProtParam free software) [42].

SRCD spectra are expressed in delta epsilon units, calculated using mean residue weight of 86,138 Da for $r \mathrm{Cyt}_{558}$ (considering 767 as the total number of residues for gp91 ${ }^{\text {phox }}$ and p22 $2^{\text {phox }}$ ). The analysis of the CD data has been performed using two algorithms SELCON3 [43] or the recent software BeStSel [44]. Similar behaviors of the secondary structure contents were obtained with both programs. The fitting range was $180-250 \mathrm{~nm}$ and no scaling factor has been applied. 


\section{Results}

\subsection{Temperature dependence of the NADPH oxidase activity in yeast ER and plasma membranes}

In order to explore how the temperature interferes into the regulation of superoxide anion production rates, cell free assay measurements were carried out over the temperatures range $10-40{ }^{\circ} \mathrm{C}$. The final concentrations of AA needed for maximal activation with ER and PM have been previously optimized and deduced from concentration-response curves that plot the enzyme activity $v s$ the AA concentration [30]. No significant difference of the optimal AA concentration could be identified for ER and PM. Figure 1A shows the temperature dependence of NADPH oxidase specific activity $\left(k_{\text {cat }}\right)$ for both subcellular PM and ER membranes containing $r \mathrm{Cyt} b_{558}$. The superoxide anion production rate constants rise exponentially with temperature reflecting a thermally activated process which was more important in ER than in plasma membranes.

The Arrhenius plots derived from the temperature dependence of $k_{\text {cat }}$ according to Equation 2 are displayed in Figure 1B. For the whole temperature range covered by our experiments (10$40{ }^{\circ} \mathrm{C}$ ), in PM, the Arrhenius plot of NADPH oxidase activity yielded a linear relationship. The apparent activation energy $\mathrm{E} a$ deduced from the slope was of $81.7 \pm 14.6 \mathrm{~kJ} \cdot \mathrm{mol}^{-1}$. Conversely, in ER membrane, the Arrhenius plot displayed a break at the temperature of about $23 \pm 2{ }^{\circ} \mathrm{C}$. To determine the activation parameters above and below this temperature, linear regressions were performed on both sides of this temperature. The thermodynamic parameters derived from these plots are shown in Table I. Above $23{ }^{\circ} \mathrm{C}$, the activation energy was found to be of about $73 \pm 10 \mathrm{~kJ} \mathrm{~mol}^{-1}$ close to the value obtained in PM, while below 23 ${ }^{\circ} \mathrm{C}$, the apparent $\mathrm{E} a$ value is twice larger $\left(166 \pm 30 \mathrm{~kJ} \mathrm{~mol}^{-1}\right)$. The similarity of $\mathrm{E} a$ above 23 ${ }^{\circ} \mathrm{C}$ in ER and in PM suggests that the superoxide production is rate-limited by the same cause. The high activation energy below $23{ }^{\circ} \mathrm{C}$ suggests that other limiting steps might be implicated.

\subsection{Comparison of the temperature dependencies in ergosterol or cholesterol- supplemented ER and in sterol-depleted plasma membranes}

To give some explanations to the different thermodynamic behaviors in PM and ER, we varied the sterol contents and performed cell free assays over the same temperature range as above. In eukaryotes, the major sterols found are ergosterol and cholesterol in yeast and mammalian cells, respectively. The structures of cholesterol and ergosterol are similar, except 
that ergosterol contains an additional double bond in the B ring and a double bond between carbons 22-23 (Figure S1). Either in mammals or in yeasts, plasma membranes are enriched in sterols while the content of sterol in ER membranes is rather limited. In $S$. cerevisae, the ergosterol/proteins ratio $(w: w)$ are known to be about $0.45 \%$ and $0.05 \%$ in PM and ER, respectively [34]. Based on these values, we supplemented ER with either ergosterol or cholesterol in order to reach a similar ratio than in plasma membranes and we carried out cell free assay measurements over the temperature range $10-40^{\circ} \mathrm{C}$. The temperature dependencies of the superoxide anion production for ergosterol- and cholesterol-ER membranes are displayed in Figure 2A. Similar temperature dependencies of NADPH oxidase activity were found albeit slight decreases in the rates of the superoxide anion observed, compared to native ER membranes (Table 1). Interestingly, the Arrhenius plots of ER after addition of either ergosterol or cholesterol displayed no more breaks (Figure 2B). The activation energy (E $a$ )

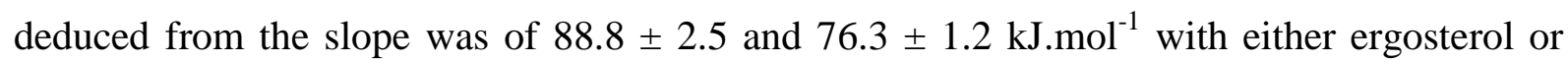
cholesterol, respectively. The values are now close to the one determined for PM. The introduction of sterols modified the thermodynamic behavior of the oxidase activity in ER bringing evidence of the correlation between the membrane composition and the thermodynamic behavior of the process occurring during the NADPH oxidase turn-over.

A complementary experiment was performed by depleting ergosterol from the plasma membrane using a sterol sequestering compound, methyl- $\beta$-cyclodextrine (M $\beta C D)$. As observed in Figure 3A, the ergosterol depleted yeast PM displayed a drastically increased temperature dependence of NADPH oxidase activity. Moreover, the depletion of ergosterol reintroduced unexpectedly a break at about $25^{\circ} \mathrm{C}$ in the slope of the Arrhenius plot (Figure $3 \mathrm{~B})$. Above $25^{\circ} \mathrm{C}$, the activation energy was of about $75 \mathrm{~kJ} \cdot \mathrm{mol}^{-1} \pm 15 \mathrm{~kJ} \cdot \mathrm{mol}^{-1}$, close to the value obtained in PM, while below, the $\mathrm{E} a$ value was $220.8 \pm 3 \mathrm{~kJ}^{\mathrm{mol}}{ }^{-1}$.

The presence of such breaks in the Arrhenius plot can be correlated to membrane environment properties that are classically related to lipid phase transition states. We showed that this transition was modulated by the sterol content. Taken as a whole, these results showed that the kinetics parameters of the NADPH oxidase activity are sensitive to the lipid composition.

\subsection{Temperature dependence of SRCD spectra}

No structural data are yet available for the membrane Cyt $b_{558}$. The SRCD spectra obtained for the DDM-solubilized recombinant $r \mathrm{Cyt} b_{558}$ as a function of temperature are shown in Figure 4. The SRCD spectra display a positive band peaking at $194 \mathrm{~nm}$, a negative peak near $210 \mathrm{~nm}$ and a shoulder around $222 \mathrm{~nm}$. The secondary structure of $r \mathrm{Cyt} b_{558}$ determined from the 
analysis of the spectrum by SELCON3 algorithm is composed, at $25^{\circ} \mathrm{C}$, of high amounts of $\alpha$-helixes $(\approx 51 \%$ ), low amount of $\beta$-sheets $(\approx 14 \%)$ and a high percentage of turns and unordered secondary structure $(\approx 35 \%)$. The secondary structures needed cautious examination due to possible inaccuracies of membrane protein concentration in detergent micelles. Nevertheless, the high composition in $\alpha$-helixes was consistent with the putative six transmembrane helices of Nox 2 and at least two of $\mathrm{p} 22^{\text {phox }}$.

We have collected and repeated reproducibly the SRCD spectra in the temperature range 20$90{ }^{\circ} \mathrm{C}$ in steps of $5{ }^{\circ} \mathrm{C}$. This set of spectra has been analyzed in terms of secondary structures. The changes in secondary structure composition of DDM-purified $r \mathrm{Cyt} b_{558}$ as a function of temperature, shown in Figure 5A, are consistent with partial unfolding of helical structures concomitantly with an increase of unordered conformations. This decrease of the helical folded state with temperature can be fitted with a sigmoid curve with a simple two-state unfolding process of helixes. The resulting melting temperature is at $60{ }^{\circ} \mathrm{C}$. This indicated that the unfolding process of helixes and appearance of unordered structures during heating are concerted. The slight increase of the sheet content with temperature occurs with linearity indicating more stable structures. Hence it was possible to establish that $r \mathrm{Cyt} b_{558}$ was stable without major secondary structure changes between $20-40{ }^{\circ} \mathrm{C}$. The changes in ellipticity as a function of temperature were monitored at characteristic wavelengths: 195, 210 and $222 \mathrm{~nm}$ (Figure 5B). The $222 \mathrm{~nm}$-peak reflects the helix content while the $210 \mathrm{~nm}$ peak is due to a mixture of sheets and helix content and $195 \mathrm{~nm}$, to a mixture of helixes, sheets and unfolded structures. To determine the thermodynamics of conformational changes we used the Van't Hoff equation (equation (5)). The enthalpies of unfolding $(\Delta \mathrm{H})$ at 195, 210 and $222 \mathrm{~nm}$ (Figure 5B) from Van't Hoff analysis are 8.9, 4.35 and $3.9 \mathrm{~kJ} \mathrm{~mol}^{-1}$, respectively. The low contribution of helixes, either in energy or in helixes amount, to unfolding could reflect disordering of the smallest membrane $\mathrm{p} 22^{\text {phox }}$ subunit.

From these SRCD experiments we could conclude that the helixes and unordered structures are mainly the elements involved in the thermal transition around $60{ }^{\circ} \mathrm{C}$. The fact that $r \mathrm{Cyt} b_{558}$ is stable up to $60{ }^{\circ} \mathrm{C}$ allowed excluding any major unfolding process in the $20-40{ }^{\circ} \mathrm{C}$ temperature range explored in this work.

\subsection{Artificial cell-free assay with $r$ Cytb $_{558}$ reconstituted into liposomes}

It was previously shown that purified DDM- $r \mathrm{Cyt} b_{558}$ incorporated into lipid bilayers restored the NADPH oxidase activity lost after detergent solubilization [30, 33]. We further decided to 
remove $r \mathrm{Cyt} b_{558}$ from the yeast membrane environment and to reconstitute it into liposomes of either DOPC $\left(18: 1 / 18: 1\right.$; Tm of $\left.-18.3{ }^{\circ} \mathrm{C}\right)$ or DMPC $\left(14: 0 / 14: 0\right.$; $\mathrm{Tm}$ of $\left.23{ }^{\circ} \mathrm{C}\right)$ in order to follow the enzyme activity within "artificial" cell free assays. In this system, the superoxide production rates were measured at different arachidonic acid concentrations (Figure 6). For DOPC and DMPC proteoliposomes, we found a similar bell shape pattern of the doseresponse curves that plots the enzyme activity $v s$ the AA concentration. Such curves are characteristic of phagocyte NADPH-oxidase activation, indicating that the activation process using the activator molecule, AA, is similar to that of native enzyme (reviewed in [45]). The optimal AA concentration for maximal NADPH oxidase specific activity $\left(\approx 160-170 \mathrm{~s}^{-1}\right)$ was about $650 \mu \mathrm{M}$ for both types of proteoliposomes and was used in further experiments.

\subsection{Temperature dependence of the NADPH oxidase activity in reconstituted proteoliposomes}

The temperature dependences of specific NADPH oxidase activity $r \mathrm{Cyt} b_{558}$ reconstituted in either DOPC-PL or DMPC-PL are shown in Figure 7A. We observed for the proteoliposomes, as for yeast membranes, a superoxide anion production which increases exponentially with temperature. Above $20{ }^{\circ} \mathrm{C}$, the temperature dependence is much more pronounced in DMPCPLs than in DOPC-PLs.

The Arrhenius plots derived from the temperature dependence of $k_{\text {cat }}$ are displayed in Figure 7B. In the whole temperature range covered by our experiments $\left(15-40^{\circ} \mathrm{C}\right)$, in DOPC-PLs, Arrhenius plot of NADPH oxidase activity yielded a linear relationship. Due to the very low $\operatorname{Tm}\left(-18.3{ }^{\circ} \mathrm{C}\right)$, DOPC-PLs exhibit a fluid phase throughout the temperature range studied. The apparent E $a$ deduced from the slope was of $71.7 \pm 3.7 \mathrm{~kJ} . \mathrm{mol}^{-1}$. This value is close to that obtained with PM. In DMPC-PLs, the Arrhenius plots display a break at the temperature at about $29 \pm 2{ }^{\circ} \mathrm{C}$. This break is correlated to the gel-to-liquid lipid transition, except that the presence of $r \mathrm{Cyt} b_{558}$ might have increased slightly the transition temperature of pure DMPC vesicles $\left(23-24{ }^{\circ} \mathrm{C}\right)$. It is known that membrane proteins may modify the Tm value and may induce an upward shift of the lipid melting point [46, 47]. Above $29^{\circ} \mathrm{C}$, the activation energy was about $77.3 \pm 3.3 \mathrm{~kJ} \mathrm{~mol}^{-1}$ close to the value obtained in $\mathrm{PM}$, while, below $29{ }^{\circ} \mathrm{C}$, the $\mathrm{E} a$ value of $154 \pm 18 \mathrm{~kJ} \mathrm{~mol}^{-1}$ was found. Complementation of DMPC-PLs with ergosterol induced a decrease of the temperature dependence as displayed in Figure 8A and in parallel, removed the break of the Arrhenius plot (Figure 8B) and restored an Ea value $(96.6 \pm 4.6$ $\mathrm{kJ} . \mathrm{mol}^{-1}$ ) close to that of PM. 


\section{Discussion}

In spite of the importance of NADPH oxidase in infection defense and inflammation, limited data about its temperature dependence are described. The largest range of temperature dependence of the NADPH oxidase activity was explored in eosinophils [48] and in solubilized preparation of Cyt $b_{558}$ from pig neutrophils [49]. The difficulty arises from the short-lifetime of superoxide anions at high temperature. Most studies of the NADPH oxidase activity have been made at standard temperature $\left(25-30{ }^{\circ} \mathrm{C}\right)$, or at physiological temperature $\left(37{ }^{\circ} \mathrm{C}\right)$. Such studies are convenient to have access to the so-called $Q_{10}$ parameter (used for evaluation of the temperature dependence of a process) as calculated in [48] from different published data. Nevertheless a thorough study of the temperature dependence is required on a physiological temperature range, keeping other parameters constant. The rates that we have collected were plotted in an Arrhenius plot, which yields the activation energy that infers precise thermodynamic information about the process. At the same time, temperature, as well as other factors such as lipid composition, controls the membrane physical state. For this reason, these experiments were also performed with designed lipid membranes. Consequently, our results provide novel information that could not have been obtained using canonical assays on entire cells or membrane fractions.

The main observations are:

1. A relationship between the initial rate of superoxide production and the membrane composition. We demonstrated that the level of sterol modified this rate.

2. The initial rate of superoxide produced by $r \mathrm{Cyt} b_{558}$ is strongly temperature dependent and increases exponentially with temperature whatever the membrane composition.

3. Linear Arrhenius plots are obtained between $10-40{ }^{\circ} \mathrm{C}$ in PM and DOPC-PLs, or in ER and DMPC-PLs supplemented with ergosterol/cholesterol with $\mathrm{E} a$ values ranging from 71 to $96 \mathrm{~kJ} \mathrm{~mol}^{-1}$. This linearity is consistent with the idea that a single process is rate determining over this temperature range.

4. A break in linearity of Arrhenius plot is observed around $23{ }^{\circ} \mathrm{C}, 25^{\circ} \mathrm{C}$ and $29^{\circ} \mathrm{C}$ in $\mathrm{ER}$, in sterol-free PM and in DMPC-PLs, respectively. We consider this behavior to reflect the impact of membrane viscosity on the thermodynamic process of oxidase activity.

\section{Membrane composition effect}


Membranes are crucial, since they separate the cytosol from the extracellular or phagosomal environment and also maintain the subcellular organelle characteristics. Phagocyte and non-phagocyte NADPH oxidases are found in various subcellular compartments (plasma membrane, phagosome, ER, mitochondria..) but still little is known about the Cyt $b_{558}$-lipid interactions and the influence of lipids on the superoxide anion production process. The membrane composition was already considered an important factor for NADPH oxidase activity [33, 50]. In a previous work, despite very similar properties of the recombinant $C y t b_{558}$ expressed at the level of yeast ER and PM (i.e., same $\mathrm{K}_{\mathrm{m}}$, same spectra, similar arachidonic acid dependent bell-shape activation curves), a substantially higher NADPH oxidase activity was measured at $25^{\circ} \mathrm{C}$ in yeast ER compared to plasma membrane that was suggested to be related to the sterol content [30]. Indeed the different membrane organelles of mammalian and yeast cells are not homogeneous in particular regarding the sterol content [34]. In this work, our results support this idea. Indeed we showed that after cholesterol/ergosterol addition to ER, the NADPH oxidase activity decreased (Table 1). We confirmed this conclusion in artificial cell-free oxidase system, since the NADPH oxidase activity is declined in DMPC-PLs supplemented with cholesterol $\left(190 \mathrm{~mol} \mathrm{O}_{2}{ }^{-{ }^{-} / \mathrm{s} / \mathrm{mol}}\right.$ Cyt $\left.b_{558}\right)$ and in particular with ergosterol $\left(158 \mathrm{~mol} \mathrm{O}_{2}{ }^{-} / \mathrm{s} / \mathrm{mol}\right.$ Cyt $\left.b_{558}\right)$ compared to singlelipid experiments. In contrast ergosterol-free PM using cyclodextrins drastically increased the oxidase activity. The NADPH oxidase activity was influenced by the removal of cholesterol or ergosterol from PM by agents such as $\mathrm{M} \beta \mathrm{CD}$, known to disorganize lipid microdomains (or lipid rafts). We could hypothesize that rCytb558 was localized in these microdomains. Altogether, cholesterol/ergosterol could be considered to be efficient negative regulators of the NADPH oxidase activity. However how sterols lowered the NADPH oxidase activity was not explained. The presence of cholesterol-binding motifs (or "CRAC" for cholesterol recognition/interaction amino acid consensus) adjacent to transmembrane helices of gp91 ${ }^{\text {phox }}$ and $\mathrm{p} 22^{\text {phox }}$, that we have previously identified [30], allows conceivable interactions between cholesterol and $\mathrm{Cyt} b_{558}$ and may explain at the molecular level the sterol sensitivity of the NADPH oxidase activity. However, one might expect that Cyt $b_{558}$ is regulated not only by specific interactions but also, more generally, by bilayer interactions at the macroscopic level. Enzyme activities or protein agglomeration or protein-lipid segregation have been shown to be dependent on bilayer thickness (or hydrophobic mismatch; reviewed in [51, 52]). Indeed ER membrane thicknesses are known to be smaller $(\approx 37 \AA$ ) than those of plasma membranes $(\approx 42 \AA)$. Based on our data, for $r \mathrm{Cyt} b_{558}$, smaller bilayer thickness would then correlate with higher oxidase activity. This is in agreement with the higher superoxide production rate 
measured with DMPC-PLs than with DOPC-PLs. The hydrocarbon tail of DMPC comprise only single bonds (14 carbons) while DOPC, one of the most typical cell membrane lipids, contain a tail of 18 carbon atoms and one double-bond in the middle. In this respect, the cholesterol increases membrane thickness. Altogether it suggests that the increase of the membrane thickness (by the presence of sterols or long fatty acid) induces a decrease of NADPH oxidase activity.

\section{Thermal stability of $\mathrm{Cyt}_{558}$}

It has been previously observed that it was not possible to measure the effect of temperature above $25{ }^{\circ} \mathrm{C}$ with solubilized $\mathrm{Cyt} b_{558}$ preparation due to a loss of the heme moiety. This observation was in fact related to the use of an inappropriate detergent mixture[49]. Here, the stability of solubilized $r$ Cytb558 was assessed by following the change in the whole SRCD spectrum and in the magnitude of specific peaks as function of temperature. We showed the thermal stability of DDM-solubilized $r \mathrm{Cyt} b_{558}$ with increasing temperature, the melting point of the unfolding transition being around $60{ }^{\circ} \mathrm{C}$. The thermal characteristics determined at 195 $\mathrm{nm}, 210$ and $222 \mathrm{~nm}$ indicated that the unfolding process of the different secondary structures is concerted and involves principally the helix secondary structures. Thus, in the experimental temperature below $40{ }^{\circ} \mathrm{C}$, the temperature dependencies of oxidase activity measured cannot be related in any case to protein instability.

\section{Thermal activation of NADPH oxidase activity}

In our experiments, the incubation procedure of the oxidase subunits at different temperatures allows assembly of NADPH oxidase complexes. Thus, since the complexes are already assembled, the rise of superoxide production rate with increasing temperature reflects higher turnover rates. This assumption is comforted by earlier data of NADPH oxidase activity determined by reduction of Cyt $c$ as function of temperature, as described here, showing that the activation and assembly steps are not the limiting step [49, 53]. We have measured the rates of superoxide production by $r \mathrm{Cyt} b_{558}$ from 10 up to $40{ }^{\circ} \mathrm{C}$ (above $40{ }^{\circ} \mathrm{C}$, the kinetics were difficult to determine). However we observed no optimal enzyme activity at body temperature $\left(37^{\circ} \mathrm{C}\right)$ as it was postulated [48]. Exposure of neutrophils to long hyperthermia period was shown to induce transient inhibition of NADPH oxidase ( $25 \%$ at $40{ }^{\circ} \mathrm{C}$ ) [54]. But we did not observe any decrease of the activity at $40{ }^{\circ} \mathrm{C}$. Consistently, NADPH oxidase activity inhibition was suggested not to result from heat denaturation of the enzyme but rather from impairment of their membrane assembly [55] imputable to the cytoskeleton [56] and 
denaturation of $\mathrm{p} 67^{\mathrm{phox}}\left(>46{ }^{\circ} \mathrm{C}\right)$ [57]. These results indicate clearly that $37{ }^{\circ} \mathrm{C}$ is not a temperature threshold for the NADPH oxidase activity and are compatible with the idea that fever elevates immune reactivity. Our system behaves like a "normal" chemical system whose rate constant increases with the temperature. Thus, in our cell-free system where cellular events are circumvented, the enzyme is activated by increased temperature.

\section{Thermodynamics of the NADPH oxidase activity}

In the whole temperature range covered by our experiments $\left(10-40{ }^{\circ} \mathrm{C}\right)$, Arrhenius plots with PM yielded linear relationships with the $\mathrm{E} a$ value $\left(c a .80 \mathrm{~kJ} \mathrm{~mol}^{-1}\right.$, i.e. 19.5 kcal.mol ${ }^{-1}$ ), close to that obtained with membrane fraction of eosinophils (about $25 \mathrm{kcal}_{\mathrm{mol}}{ }^{-1}$, i.e. $100 \mathrm{~kJ} \mathrm{~mol}^{-1}$; [48]). This behavior obeys to Arrhenius' law and can be explained by the homogeneity of the membranes. PM are believed to be in a liquid disordered $\left(\mathrm{L}_{\mathrm{d}}\right)$-phase. Similar E $a$ values can be found in all experiments where membranes are in fluid (or liquid disordered) state of lipids $\left(\mathrm{L}_{\mathrm{d}}\right)$, i.e. in DOPC-PLs and DMPC-PLs above Tm. In ER membranes, above $23{ }^{\circ} \mathrm{C}$, the activation energy is of similar magnitude, but surprisingly below $23{ }^{\circ} \mathrm{C}$, the data points diverged from the linear function defined by the other data points leading to a very high $\mathrm{E} a$ value $\left(166 \mathrm{~kJ} \mathrm{~mol}^{-1}\right)$. Such high activation energy is also found in DMPC-PLs below Tc where lipids are in their gel phase $\left(\mathrm{L}_{\beta}\right)$ suggesting that the superoxide production is rate-limited by the same event.

Although the observation for ER membranes was unexpected, our data suggest that yeast ER membranes with $r \mathrm{Cyt} b_{558}$ undergo lipid transition around $23^{\circ} \mathrm{C}$. More importantly we showed that the NADPH oxidase is sensitive to gel-to-fluid transition that can regulate the energetic parameter of the oxidase activity. This suggests that oxidase functioning depends little on specific lipid-protein interactions but rather on the membrane properties including thickness and fluidity (see scheme 1). The change of $\mathrm{E} a$ of NADPH oxidase activity upon the membrane state indicates that $r \mathrm{Cyt} b_{558}$ needs a relatively fluid environment (i. e. $\mathrm{L}_{\mathrm{d}}$ ) to optimally perform intramolecular electron transfer from $\mathrm{FADH}_{2}$ to oxygen. This might explain the lower activity measured in B cells compared to neutrophils and which was attributed to a blockage of the protein in an inactive state due to the lipid environment [58].

Fluctuations in lipid composition that determine the bilayer properties, and consequently the energetics of the NADPH oxidase activity can occur during cell signaling events of the immune response among the different membrane compartments. Bilayer phase transitions can introduce a protein segregation behavior leading to membrane proteins aggregation below the 
transition temperature [59-62], which leads to an even higher increase of the local viscosity. It was established that protein-protein contacts become the major phenomenon below the phase transition temperature. Close spatial relationship or direct interactions were demonstrated to exist between the Cyt $b_{558}$ and other membrane proteins located in the redox signaling rafts [32]. Whatever the protein-protein contacts, either between oxidases and other membrane proteins (receptors, enzymes, channels...) or between oxidases themselves, these interactions may influence the thermodynamics of the superoxide generation process. The dependence of the arrangement of $\mathrm{Cyt}_{558}$ within the lipid bilayer is interesting regarding its enzymatic specificity. In addition to immobilization of the hydrocarbon chains of the oxidase, electrostatic effects due to the interactions between some charged residues can intervene. Structural data at low resolution on the protein organization within the membrane will probably contribute to a better understanding of these phenomena.

\section{Conclusion}

Increased temperature kills microorganisms and facilitates the immune response. We showed that the key element of an enhanced production of reactive species by the NADPH oxidase seemed to be related to the membrane fluidity and thickness. In addition, temperature controls, together with other factors such as lipid composition, the membrane phase transition. Therefore we inspected how lipid membrane properties might contribute to the NADPH oxidase activity that may occur in immune response or inflammatory events. We used a NADPH oxidase model system free from the signaling pathways complexity. We showed that high temperature enhances production rates of superoxide anions. Our in vitro results show that membrane physicochemical properties control the oxidase activity.

\section{Acknowledgments}

The Agence Nationale de la Recherche (ANR-2010-BLAN-1536-01) is acknowledged for financial support. Authors want to acknowledge Dr. M-C Dagher for providing with the cytosolic protein containing plasmids. CD measurements on DISCO beamline at the SOLEIL synchrotron facility were performed under proposal 20140304.

\section{References}


[1] S. O'Neill, J. Brault, M.J. Stasia, U.G. Knaus, Genetic disorders coupled to ROS deficiency, Redox Biology 6 (2015) 135-156.

[2] A.R. Cross, O.T. Jones, Enzymic mechanisms of superoxide production, Biochim Biophys Acta 1057 (1991) 281-298.

[3] R.H. Burdon, Superoxide and hydrogen peroxide in relation to mammalian cell proliferation, Free Radic Biol Med 18 (1995) 775-794.

[4] H. Sumimoto, Structure, regulation and evolution of Nox-family NADPH oxidases that produce reactive oxygen species ( $\mathrm{vol}$ 275, pg 3249, 2008), Febs Journal 275 (2008) 39843984.

[5] M.T. Quinn, K.A. Gauss, Structure and regulation of the neutrophil respiratory burst oxidase: comparison with nonphagocyte oxidases, J Leukoc Biol 76 (2004) 760-781.

[6] Y. Groemping, K. Rittinger, Activation and assembly of the NADPH oxidase: a structural perspective, Biochem J 386 (2005) 401-416.

[7] F.R. Sheppard, M.R. Kelher, E.E. Moore, N.J.D. McLaughlin, A. Banerjee, C.C. Silliman, Structural organization of the neutrophil NADPH oxidase: phosphorylation and translocation during priming and activation, Journal of Leukocyte Biology 78 (2005) 1025-1042.

[8] K. Bedard, K.H. Krause, The NOX family of ROS-generating NADPH oxidases: Physiology and pathophysiology, Physiological Reviews 87 (2007) 245-313.

[9] L.C. Mcphail, D. Qualliotinemann, K.A. Waite, Cell-Free Activation of Neutrophil Nadph Oxidase by a Phosphatidic Acid-Regulated Protein-Kinase, Proceedings of the National Academy of Sciences of the United States of America 92 (1995) 7931-7935.

[10] D.S. Regier, K.A. Waite, R. Wallin, L.C. McPhail, A phosphatidic acid-activated protein kinase and conventional protein kinase $C$ isoforms phosphorylate p22(phox) NADPH oxidase component, Journal of Biological Chemistry 274 (1999) 36601-36608.

[11] C. Massenet, S. Chenavas, C. Cohen-Addad, M.C. Dagher, G. Brandolin, E. Pebay-Peyroula, F. Fieschi, Effects of p47phox $C$ terminus phosphorylations on binding interactions with p40phox and p67phox. Structural and functional comparison of p40phox and p67phox SH3 domains, J Biol Chem 280 (2005) 13752-13761.

[12] J. El-Benna, P.M.C. Dang, M.A. Gougerot-Pocidalo, J.C. Marie, F. Braut-Boucher, p47phox, the phagocyte NADPH oxidase/NOX2 organizer: structure, phosphorylation and implication in diseases, Experimental and Molecular Medicine 41 (2009) 217-225.

[13] H. Raad, M.H. Paclet, T. Boussetta, Y. Kroviarski, F. Morel, M.T. Quinn, M.A. GougerotPocidalo, P.M. Dang, J. El-Benna, Regulation of the phagocyte NADPH oxidase activity: phosphorylation of gp91phox/NOX2 by protein kinase $C$ enhances its diaphorase activity and binding to Rac2, p67phox, and p47phox, FASEB J 23 (2009) 1011-1022.

[14] P.M. Dang, H. Raad, R.A. Derkawi, T. Boussetta, M.H. Paclet, S.A. Belambri, K. Makni-Maalej, Y. Kroviarski, F. Morel, M.A. Gougerot-Pocidalo, J. El-Benna, The NADPH oxidase cytosolic component p67phox is constitutively phosphorylated in human neutrophils: Regulation by a protein tyrosine kinase, MEK1/2 and phosphatases 1/2A, Biochem Pharmacol 82 (2011) $1145-1152$.

[15] R. Dana, T.L. Leto, H.L. Malech, R. Levy, Essential requirement of cytosolic phospholipase A2 for activation of the phagocyte NADPH oxidase, J Biol Chem 273 (1998) 441-445.

[16] I. Pessach, T.L. Leto, H.L. Malech, R. Levy, Essential requirement of cytosolic phospholipase A(2) for stimulation of NADPH oxidase-associated diaphorase activity in granulocyte-like cells, Journal of Biological Chemistry 276 (2001) 33495-33503.

[17] R.K.M. Wong, A.I. Pettit, P.A. Quinn, S.C. Jennings, J.E. Davies, L.L. Ng, Advanced glycation end products stimulate an enhanced neutrophil respiratory burst mediated through the activation of cytosolic phospholipase $\mathrm{A}(2)$ and generation of arachidonic acid, Circulation 108 (2003) 1858-1864.

[18] Z. Shmelzer, N. Haddad, E. Admon, I. Pessach, T.L. Leto, Z. Eitan-Hazan, M. Hershfinkel, R. Levy, Unique targeting of cytosolic phospholipase $A(2)$ to plasma membranes mediated by the NADPH oxidase in phagocytes, Journal of Cell Biology 162 (2003) 683-692. 
[19] H. Souabni, V. Thoma, T. Bizouarn, C. Chatgilialoglu, A. Siafaka-Kapadai, L. Baciou, C. Ferreri, C. Houee-Levin, M.A. Ostuni, trans Arachidonic acid isomers inhibit NADPH-oxidase activity by direct interaction with enzyme components, Biochimica Et Biophysica ActaBiomembranes 1818 (2012) 2314-2324.

[20] J.C. Klock, J.K. Pieprzyk, Cholesterol, phospholipids, and fatty acids of normal immature neutrophils: comparison with acute myeloblastic leukemia cells and normal neutrophils, J Lipid Res. 20 (1979) 908-911.

[21] S. Brechard, S. Plancon, E.J. Tschirhart, New Insights into the Regulation of Neutrophil NADPH Oxidase Activity in the Phagosome: A Focus on the Role of Lipid and Ca2+ Signaling, Antioxidants \& Redox Signaling 18 (2013) 661-675.

[22] Y. Zhang, X. Li, H. Grassme, G. Doring, E. Gulbins, Alterations in Ceramide Concentration and $\mathrm{pH}$ Determine the Release of Reactive Oxygen Species by Cftr-Deficient Macrophages on Infection, Journal of Immunology 184 (2010) 5104-5111.

[23] M.A.O. Magalhaes, M. Glogauer, Pivotal Advance: Phospholipids determine net membrane surface charge resulting in differential localization of active Rac1 and Rac2, Journal of Leukocyte Biology 87 (2010) 545-555.

[24] M.C. Faure, J.C. Sulpice, M. Delattre, M. Lavielle, M. Prigent, M.H. Cuif, C. Melchior, E. Tschirhart, O. Nusse, S. Dupre-Crochet, The recruitment of p47(phox) and Rac2G12V at the phagosome is transient and phosphatidylserine dependent, Biology of the Cell 105 (2013) 501-518.

[25] D.M. Shao, A.W. Segal, L.V. Dekker, Lipid rafts determine efficiency of NADPH oxidase activation in neutrophils, Febs Letters 550 (2003) 101-106.

[26] S. Kannan, A. Audet, H. Huang, L.J. Chen, M. Wu, Cholesterol-rich membrane rafts and Lyn are involved in phagocytosis during pseudomonas aeruginosa infection, Journal of Immunology 180 (2008) 2396-2408.

[27] R.R. Malla, H. Raghu, J.S. Rao, Regulation of NADPH oxidase (Nox2) by lipid rafts in breast carcinoma cells, International Journal of Oncology 37 (2010) 1483-1493.

[28] F. Vilhardt, B. van Deurs, The phagocyte NADPH oxidase depends on cholesterol-enriched membrane microdomains for assembly, Embo Journal 23 (2004) 739-748.

[29] W.X. Han, H.W. Li, V.A.M. Villar, A.M. Pascua, M.I. Dajani, X.Y. Wang, A. Natarajan, M.T. Quinn, R.A. Felder, P.A. Jose, P.Y. Yu, Lipid rafts keep NADPH oxidase in the inactive state in human renal proximal tubule cells, Hypertension 51 (2008) 481-487.

[30] H. Souabni, P. Machillot, L. Baciou, Contribution of lipid environment to NADPH oxidase activity: influence of sterol, Biochimie 107 Pt A (2014) 33-42.

[31] R. Masoud, T. Bizouarn, C. Houee-Levin, Cholesterol: A modulator of the phagocyte NADPH oxidase activity - A cell-free study, Redox Biology 3 (2014) 16-24.

[32] S. Jin, F. Zhou, F. Katirai, P.L. Li, Lipid Raft Redox Signaling: Molecular Mechanisms in Health and Disease, Antioxidants \& Redox Signaling 15 (2011) 1043-1083.

[33] M.A. Ostuni, L.B. Lamanuzzi, T. Bizouarn, M.C. Dagher, L. Baciou, Expression of functional mammal flavocytochrome $b(558)$ in yeast: Comparison with improved insect cell system, Biochimica Et Biophysica Acta-Biomembranes 1798 (2010) 1179-1188.

[34] H. Pichler, B. Gaigg, C. Hrastnik, G. Achleitner, S.D. Kohlwein, G. Zellnig, A. Perktold, G. Daum, A subfraction of the yeast endoplasmic reticulum associates with the plasma membrane and has a high capacity to synthesize lipids, European Journal of Biochemistry 268 (2001) 23512361.

[35] D.R. Light, C. Walsh, A.M. O'Callaghan, E.J. Goetzl, A.I. Tauber, Characteristics of the cofactor requirements for the superoxide-generating NADPH oxidase of human polymorphonuclear leukocytes, Biochemistry 20 (1981) 1468-1476.

[36] J. Lacapère, F. Delavoie, H. Li, G. Péranzi, J. Maccario, V. Papadopoulos, B. Vidic, Structural and functional study of reconstituted peripheral benzodiazepine receptor, Biochem Biophys Res Commun. 284(2) (2001) 536-541. 
[37] F. Morel, J. Doussiere, M.J. Stasia, P.V. Vignais, The Respiratory Burst of Bovine Neutrophils Role of a B-Type Cytochrome and Coenzyme Specificity, European Journal of Biochemistry 152 (1985) 669-679.

[38] L. Baciou, M. Erard, M.C. Dagher, T. Bizouarn, The cytosolic subunit p67phox of the NADPHoxidase complex does not bind NADPH, FEBS Lett 583 (2009) 3225-3229.

[39] A. Giuliani, F. Jamme, V. Rouam, F. Wien, J.L. Giorgetta, B. Lagarde, O. Chubar, S. Bac, I. Yao, S. Rey, C. Herbeaux, J.L. Marlats, D. Zerbib, F. Polack, M. Refregiers, DISCO: a low-energy multipurpose beamline at synchrotron SOLEIL, Journal of Synchrotron Radiation 16 (2009) 835-841.

[40] M. Refregiers, F. Wien, H.P. Ta, L. Premvardhan, S. Bac, F. Jamme, V. Rouam, B. Lagarde, F. Polack, J.L. Giorgetta, J.P. Ricaud, M. Bordessoule, A. Giuliani, DISCO synchrotron-radiation circular-dichroism endstation at SOLEIL, Journal of Synchrotron Radiation 19 (2012) 831-835.

[41] F. Wien, B.A. Wallace, Calcium fluoride micro cells for synchrotron radiation circular dichroism spectroscopy, Applied Spectroscopy 59 (2005) 1109-1113.

[42] H.C. Gasteiger E., Gattiker A., Duvaud S., Wilkins M.R., Appel R.D., Bairoch A., Protein Identification and Analysis Tools on the ExPASy Server;, John M. Walker (ed) ed., Humana Press 2005.

[43] N. Sreerama, R.W. Woody, Estimation of protein secondary structure from circular dichroism spectra: Comparison of CONTIN, SELCON, and CDSSTR methods with an expanded reference set, Analytical Biochemistry 287 (2000) 252-260.

[44] A. Micsonai, F. Wien, L. Kernya, Y.H. Lee, Y. Goto, M. Refregiers, J. Kardos, Accurate secondary structure prediction and fold recognition for circular dichroism spectroscopy, Proceedings of the National Academy of Sciences of the United States of America 112 (2015) E3095-E3103.

[45] M.C. Dagher, E. Pick, Opening the black box: Lessons from cell-free systems on the phagocyte NADPH-oxidase, Biochimie 89 (2007) 1123-1132.

[46] J. Riegler, H. Mohwald, Elastic Interactions of Photosynthetic Reaction Center Proteins Affecting Phase-Transitions and Protein Distributions, Biophysical Journal 49 (1986) 11111118.

[47] B. Piknova, E. Perochon, J.F. Tocanne, Hydrophobic Mismatch and Long-Range Protein-Lipid Interactions in Bacteriorhodopsin Phosphatidylcholine Vesicles, European Journal of Biochemistry 218 (1993) 385-396.

[48] D. Morgan, V.V. Cherny, R. Murphy, W. Xu, L.L. Thomas, T.E. DeCoursey, Temperature dependence of NADPH oxidase in human eosinophils, Journal of Physiology-London 550 (2003) 447-458.

[49] A.R. Cross, J.F. Parkinson, O.T.G. Jones, The Superoxide-Generating Oxidase of Leukocytes Nadph-Dependent Reduction of Flavin and Cytochrome-B in Solubilized Preparations, Biochemical Journal 223 (1984) 337-344.

[50] S. Shpungin, I. Dotan, A. Abo, E. Pick, Activation of the Superoxide Forming Nadph Oxidase in a Cell-Free System by Sodium Dodecyl-Sulfate - Absolute Lipid Dependence of the Solubilized Enzyme, Journal of Biological Chemistry 264 (1989) 9195-9203.

[51] A.G. Lee, How lipids affect the activities of integral membrane proteins, Biochimica Et Biophysica Acta-Biomembranes 1666 (2004) 62-87.

[52] J.A. Killian, Hydrophobic mismatch between proteins and lipids in membranes, Biochimica Et Biophysica Acta-Reviews on Biomembranes 1376 (1998) 401-416.

[53] Y. Isogai, T. lizuka, Y. Shiro, The Mechanism of Electron Donation to Molecular-Oxygen by Phagocytic Cytochrome B(558), Journal of Biological Chemistry 270 (1995) 7853-7857.

[54] I. Maridonneauparini, J. Clerc, B.S. Polla, Heat-Shock Inhibits Nadph Oxidase in HumanNeutrophils, Biochemical and Biophysical Research Communications 154 (1988) 179-186.

[55] I. Maridonneauparini, S.E. Malawista, H. Stubbe, F. Russomarie, B.S. Polla, Heat-Shock in Human Neutrophils - Superoxide Generation Is Inhibited by a Mechanism Distinct from HeatDenaturation of Nadph Oxidase and Is Protected by Heat-Shock Proteins in Thermotolerant Cells, Journal of Cellular Physiology 156 (1993) 204-211. 
[56] J.E.M. Souren, C. VanDerMast, R. VanWijk, NADPH-oxidase-dependent superoxide production by myocyte-derived H9c2 cells: Influence of ischemia, heat shock, cycloheximide and cytochalasin D, Journal of Molecular and Cellular Cardiology 29 (1997) 2803-2812.

[57] R.W. Erickson, S.E. Malawista, M.C. Garrett, G. Vanblaricom, T.L. Leto, J.T. Curnutte, Identification of a Thermolabile Component of the Human Neutrophil Nadph Oxidase - a Model for Chronic Granulomatous-Disease Caused by Deficiency of the P67-Phox Cytosolic Component, Journal of Clinical Investigation 89 (1992) 1587-1595.

[58] M.H. Paclet, A.W. Coleman, J. Burritt, F. Morel, NADPH oxidase of Epstein-Barr-virus immortalized B lymphocytes - Effect of cytochrome b(558) glycosylation, European Journal of Biochemistry 268 (2001) 5197-5208.

[59] N.A. Dencher, K.D. Kohl, M.P. Heyn, Photochemical Cycle and Light Dark-Adaptation of Monomeric and Aggregated Bacteriorhodopsin in Various Lipid Environments, Biochemistry 22 (1983) 1323-1334.

[60] L. Baciou, T. Gulikkrzywicki, P. Sebban, Involvement of the Protein Protein Interactions in the Thermodynamics of the Electron-Transfer Process in the Reaction Centers from Rhodopseudomonas-Viridis, Biochemistry 30 (1991) 1298-1302.

[61] A. Taly, L. Baciou, P. Sebban, The DMPC lipid phase transition influences differently the first and the second electron transfer reactions in bacterial reaction centers, Febs Letters 532 (2002) 91-96.

[62] J. Davoust, M. Seigneuret, P. Herve, P.F. Devaux, Collisions between N-14 and N-15 SpinLabels .2. Investigations on the Specificity of the Lipid Environment of Rhodopsin, Biochemistry 22 (1983) 3146-3151.

[63] M. Eeman, M. Deleu, From biological membranes to biomimetic model membranes., Biotechnol. Agron. Soc. Environ. 14 (4) (2010) 719-736. 


\section{Figure legends}

Figure 1: Temperature dependence (A) and Arrhenius plots (B) of NADPH oxidase activity in yeast plasma and endoplasmic reticulum membranes expressing recombinant $\mathbf{r C y t} b_{558}$. The superoxide production was measured spectrophotometrically by the rate of cytochrome c reduction at $550 \mathrm{~nm}$ as described in the materials and methods section. In the reaction mixture, plasma $(\bullet)$ or endoplasmic reticulum $(\bullet)$ membranes were incubated 5 min in the presence of recombinant cytosolic proteins and the optimal concentration of cis arachidonic acid at different temperature. All results in this figure are presented as the mean \pm SD of three independent experiments $(n=3)$.

Figure 2. A. Temperature dependence of NADPH oxidase activity in endoplasmic reticulum membranes supplemented with ergosterol $(\bullet)$ or cholesterol $(\diamond)$. The superoxide production was measured spectrophotometrically by the rate of cytochrome $c$ reduction at $550 \mathrm{~nm}$ as described in Figure 1. In the reaction mixture, endoplasmic reticulum membranes was incubated with ergosterol or cholesterol $(20 \mu \mathrm{M})$ during $5 \mathrm{~min}$ in the presence of recombinant cytosolic proteins and the optimal concentration of cis arachidonic acid at the different temperatures. The ratio [sterol]/[protein] was kept equal to $0.45(\mathrm{w} / \mathrm{w})$. B. Corresponding Arrhenius plots of NADPH oxidase activity in endoplasmic reticulum membrane supplemented with ergosterol or cholesterol $(20 \mu \mathrm{M})$. All results in this figure are presented as the mean $\pm \mathrm{SD}$ of three independent experiments $(n=3)$.

Figure 3: Temperature dependence (A) and Arrhenius plots (B) of NADPH oxidase activity in plasma membranes expressing recombinant $\mathbf{r C y t} b_{558}$ before $(\bullet)$ and after treatment with M MCD $(\diamond ; 20 \mathrm{mM})$. The superoxide production was kinetically determined by following the rate of cytochrome c reduction spectrophotometrically at $550 \mathrm{~nm}$ as described in the Figure 1. All results in this figure are presented as the mean \pm SD of three independent experiments $(n=3)$. 
Figure 4: SRCD spectra of $\mathbf{r C y t} b_{558}$ as function of temperature. The protein concentration was $2.44 \mathrm{mg} / \mathrm{ml}$. Data were collected between $20^{\circ} \mathrm{C}$ and $90{ }^{\circ} \mathrm{C}$ at 5 -deg increments.

Figure 5: Analysis of SRCD spectra of $\mathrm{rCyt}_{558}$ as function of temperature. A. Temperature dependence of the secondary structures: $\alpha$-helixes $(\diamond), \beta$-sheets $(\square)$ and unordered secondary structures $(\bullet)$ contents were obtained by analyses of CD data using SELCON 3 algorithm. The lines correspond to sigmoid fits. B. Van't Hoff analysis: at 222 $(\bullet), 210(\bullet)$ and $195(\bullet) \mathrm{nm}$. The enthalpy value is deduced from the slope of the linear regression.

Figure 6: Arachidonic acid dependence of NADPH-oxidase activity of DOPC and DMPC proteoliposomes. Activity assays were performed in cell free system with (A) DOPC-PL and (B) DMPC-PLs containing $\mathrm{rCyt} b_{558}(1 \mathrm{pmol})$ with a protein/lipid ratio equal to $1 / 5$ incubated $5 \mathrm{~min}$ in the presence of recombinant cytosolic proteins (200 $\mathrm{nM}$ of each protein) and different concentration of arachidonic acid at $25{ }^{\circ} \mathrm{C}$. The NADPH oxidase velocity initiated with the addition of $500 \mu \mathrm{M}$ NADPH was calculated by spectrophotometric measurement of the reduction of Cytc $(50 \mu \mathrm{M})$ at $550 \mathrm{~nm}$. All results in this figure are presented as the mean $\pm \mathrm{SD}$ of three independent experiments $(n=3)$. The dashed lines correspond to visual fits.

Figure 7 : Temperature dependence (A) and Arrhenius plots (B) of NADPH oxidase activity in DOPC (•) and DMPC ( $\square$ ) liposomes reconstituted with recombinant $\mathbf{r C y t} b_{558}$. The superoxide production was measured spectrophotometrically by the rate of cytochrome c reduction at $550 \mathrm{~nm}$ as described in fig 1 . In the reaction mixture, PLs were incubated $5 \mathrm{~min}$ in the presence of recombinant cytosolic proteins and the optimal concentration of cisarachidonic acid $(650 \mu \mathrm{M})$ at different temperature. All results in this figure are presented as the mean \pm SD of three independent experiments $(n=3)$.

Figure 8: Temperature dependence (A) and Arrhenius plots (B) of NADPH oxidase activity in DMPC liposomes reconstituted with recombinant $\mathbf{r C y t} b_{558}$ supplemented with ergosterol. The superoxide production was measured spectrophotometrically by the rate of cytochrome c reduction at 
$550 \mathrm{~nm}$ as described in fig 1 . In the reaction mixture, PL with a protein/lipid ratio equal to $1 / 5$ (square) were incubated with ergosterol $(20 \mu \mathrm{M}) 5 \mathrm{~min}$ in the presence of recombinant cytosolic proteins and the optimal concentration of cis arachidonic acid $(650 \mu \mathrm{M})$ at different temperature. All results in this figure are presented as the mean \pm SD of three independent experiments $(n=3)$.

\section{Figure S1: Structures of cholesterol and ergosterol}

\section{Scheme 1: Correlation observed between the bilayer phases and the NADPH oxidase} activity. The phase transition between the fluid $\left(\mathrm{L}_{\mathrm{d}}\right)$ to the gel $\left(\mathrm{L}_{\beta}\right)$ phase occurs at a specific temperature called melting temperature $\left(\mathrm{T}_{\mathrm{m}}\right)$. The $\mathrm{L}_{\mathrm{d}}$ phase is characterized by disordered acyl chains and a thinner bilayer than that the $\mathrm{L}_{\beta}$ phase where acyl chains are tightly packed. The presence of cholesterol (yellow) creates a new phase $\left(\mathrm{L}_{\mathrm{o}}\right)$ which shares the characteristics of both $\mathrm{L}_{\mathrm{d}}$ and $\mathrm{L}_{\beta}$ phases. Indeed the insertion of the cholesterol in a gel phase destabilizes the lateral organization but, in a fluid phase, favors the stretching of acyl chains and their transchain conformation. Accordingly, the lateral and rotational diffusion in phase $\mathrm{L}_{\mathrm{o}}$ is close to those measured in liquid phase, but the lipid order is there close of that of an ordered solid phase. As a result, cholesterol modifies membrane thickness of the fluid phase. The thickness in $\mathrm{L}_{\mathrm{d}}$ and $\mathrm{L}_{\mathrm{o}}$ bilayer constitute limiting steps to $\mathrm{O}_{2}{ }^{-{ }^{-}}$production by $\mathrm{Cyt} b_{558}$ and the membrane rigidity increases the energy necessary for NADPH oxidase activity. In sterol depleted membrane, or in bilayer of smaller tail length, the superoxide production is increased possibly by unveiling interacting regions with cytosolic proteins. Scheme adapted from [63]. 
Table 1

\begin{tabular}{|c|c|c|c|}
\hline & $\begin{array}{l}\mathrm{O}_{2}^{--} \text {production } \\
\text { rate }\left(30^{\circ} \mathrm{C}\right)\end{array}$ & \multicolumn{2}{|c|}{$\underset{\left(\mathbf{k J} . \mathrm{mol}^{-1}\right)}{\mathrm{E} a}$} \\
\hline & & $\mathbf{T}<\mathbf{T m}$ & $\mathbf{T}>\mathbf{T m}$ \\
\hline $\begin{array}{l}\text { Endoplasmic reticulum } \\
\text { (ER) }\end{array}$ & 190.5 & $166 \pm 30$ & $73 \pm 10$ \\
\hline ER + ergosterol & 137.8 & \multicolumn{2}{|c|}{$88.8 \pm 2.5$} \\
\hline ER+ cholesterol & 135 & \multicolumn{2}{|c|}{$76.3 \pm 1.2$} \\
\hline Plasma Membrane (PM) & 138.5 & \multicolumn{2}{|c|}{$81.7 \pm 4.6$} \\
\hline $\mathrm{Pmb}+\mathrm{M}-\beta-\mathrm{CD}$ & 401 & $220.8 \pm 3$ & $75 \pm 15$ \\
\hline DOPC-PL & 328 & \multicolumn{2}{|c|}{$71.7 \pm 3.7$} \\
\hline DMPC-PL & 436 & $145 \pm 18$ & $77.3 \pm 3.3$ \\
\hline DMPC-PL + ergosterol & 158 & \multicolumn{2}{|c|}{$96.6 \pm 4.6$} \\
\hline DMPC-PL + cholesterol & 190 & \multicolumn{2}{|c|}{ n.d. } \\
\hline
\end{tabular}

n.d.: not determined 
Figure 1
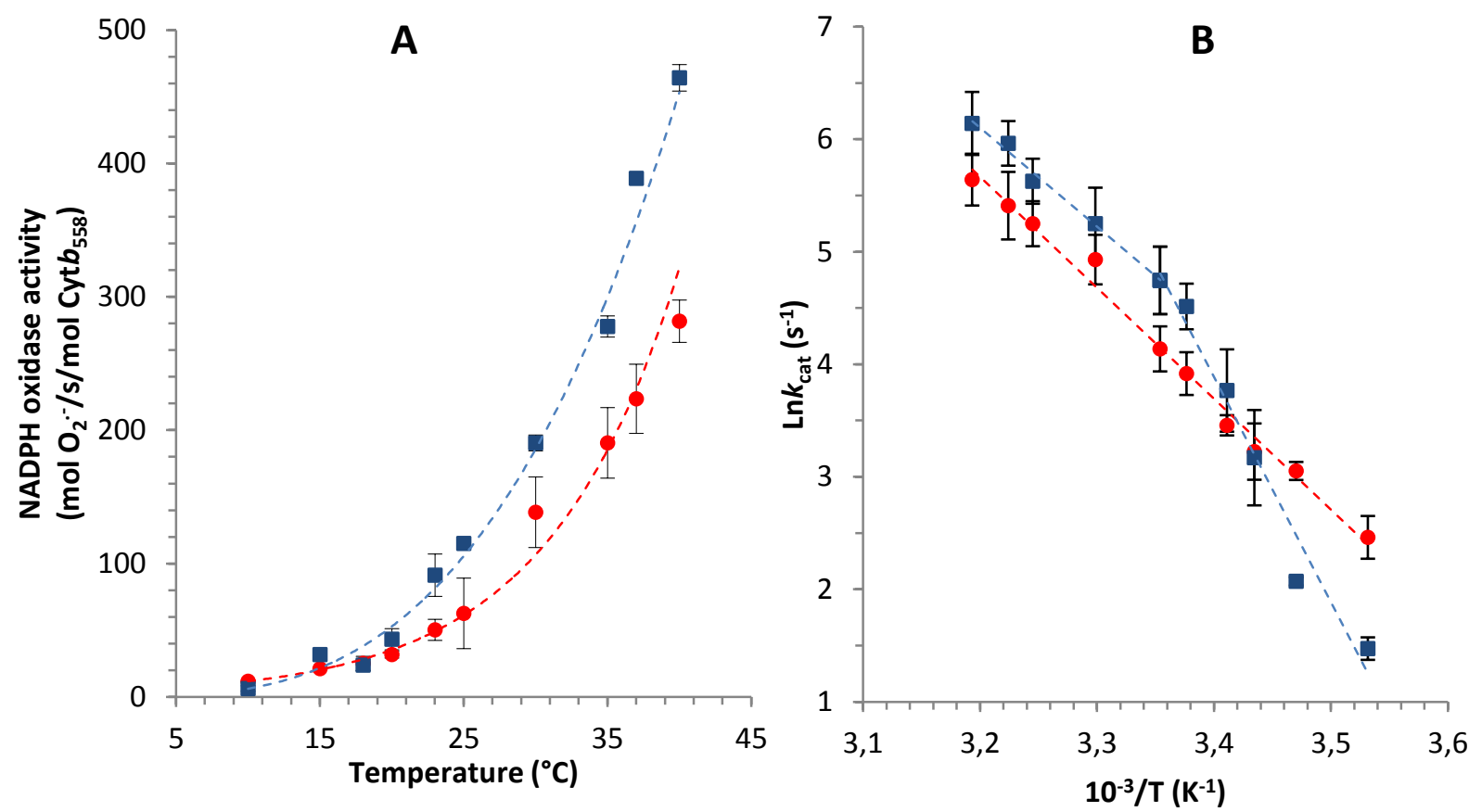
Figure 2
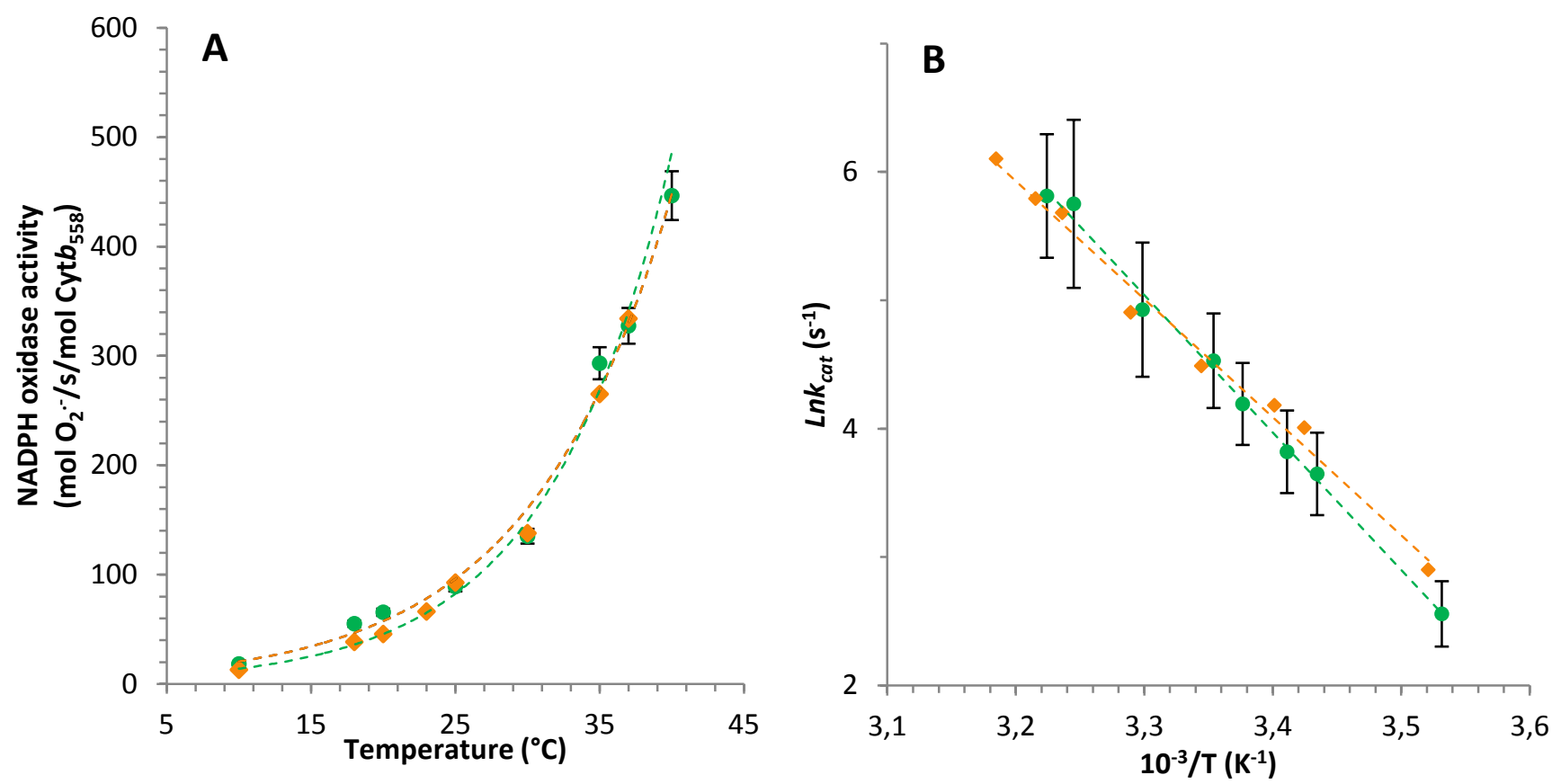
Figure 3
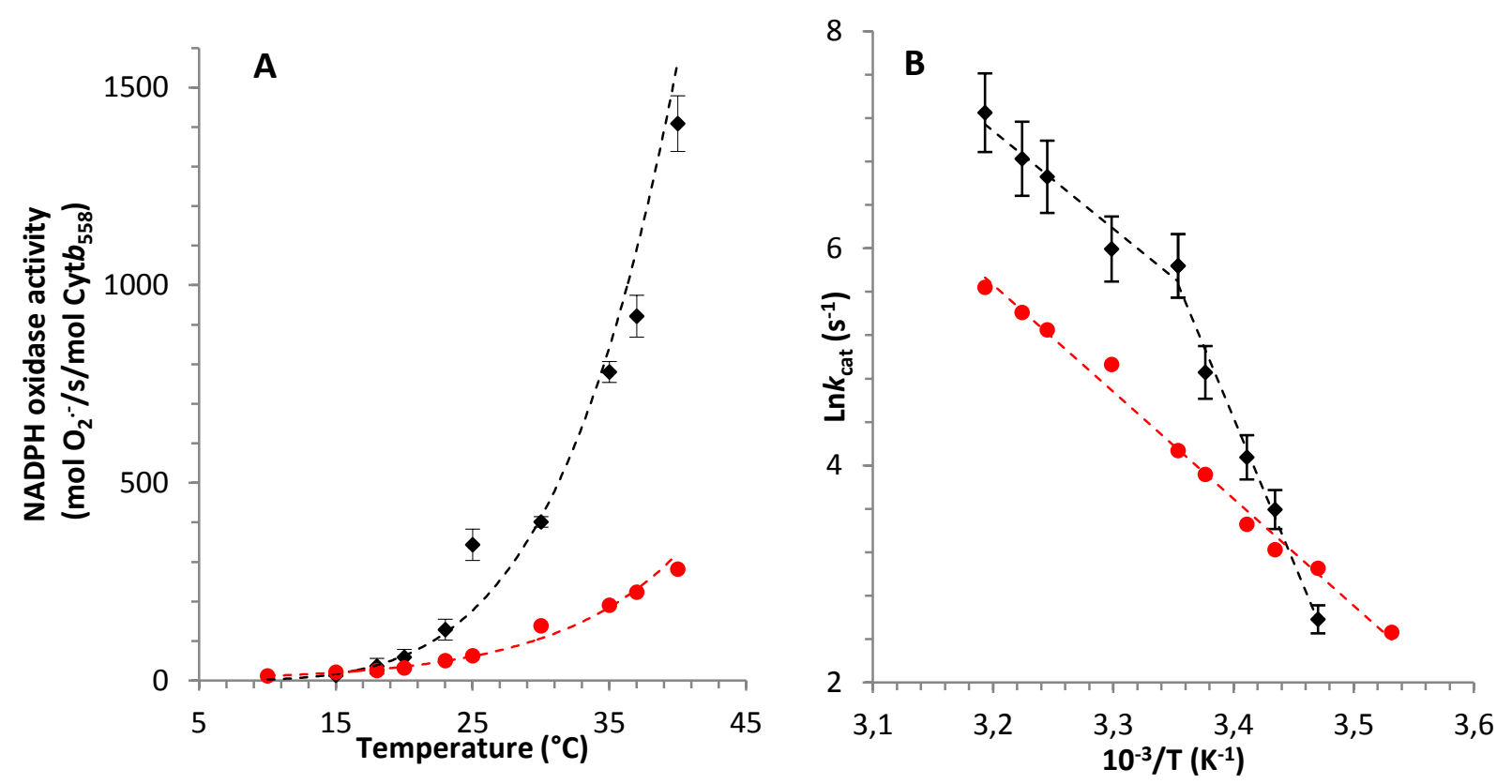
Figure 4

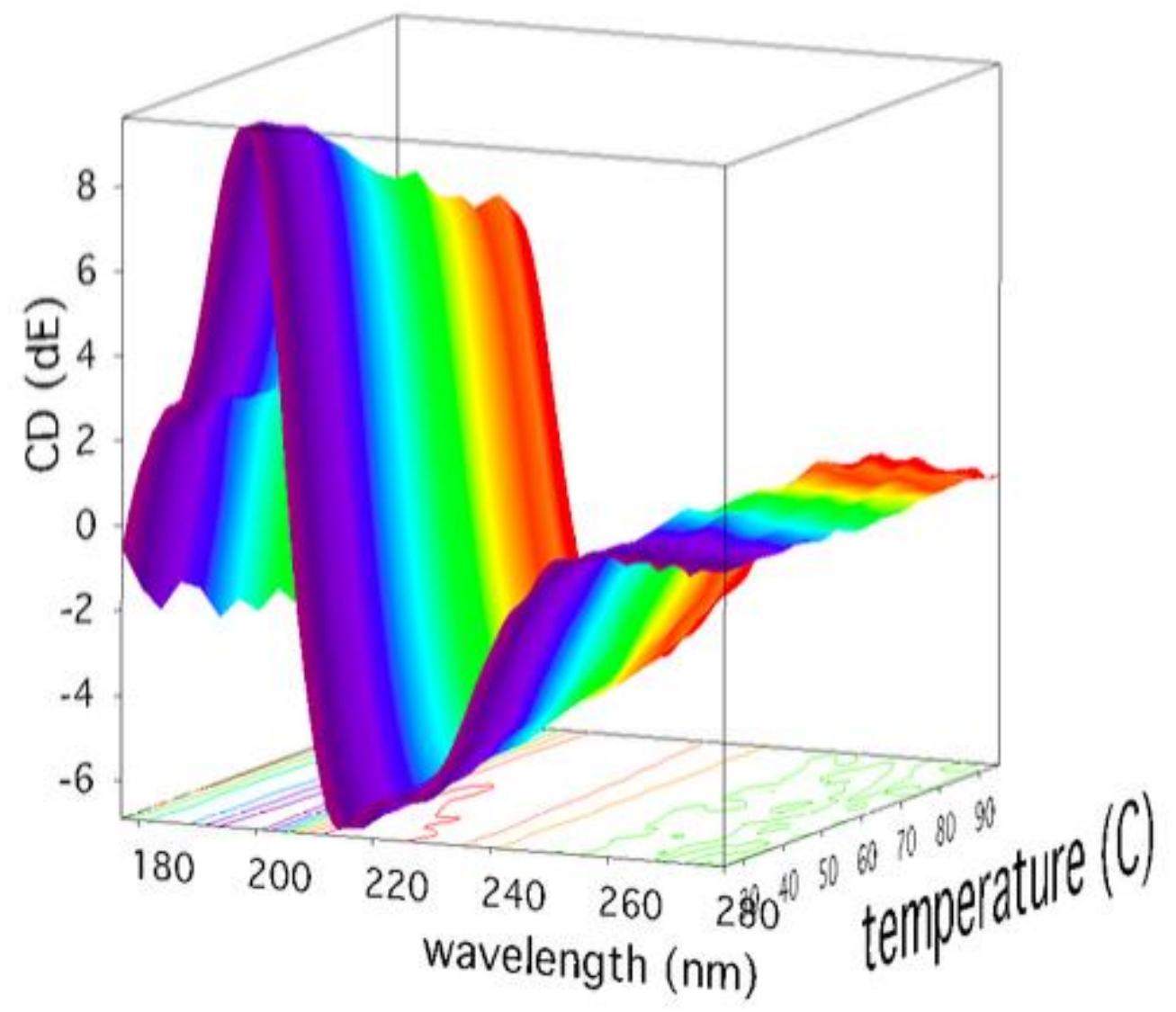


Figure 5

A

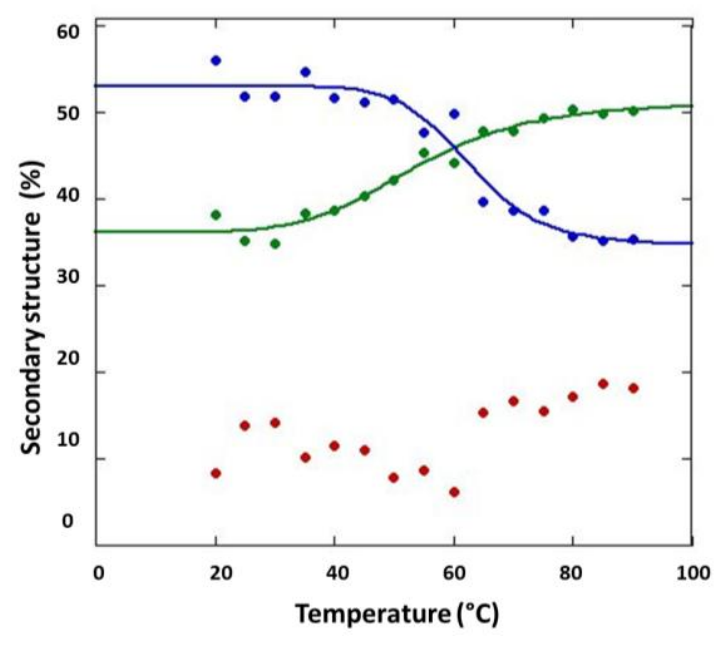

B

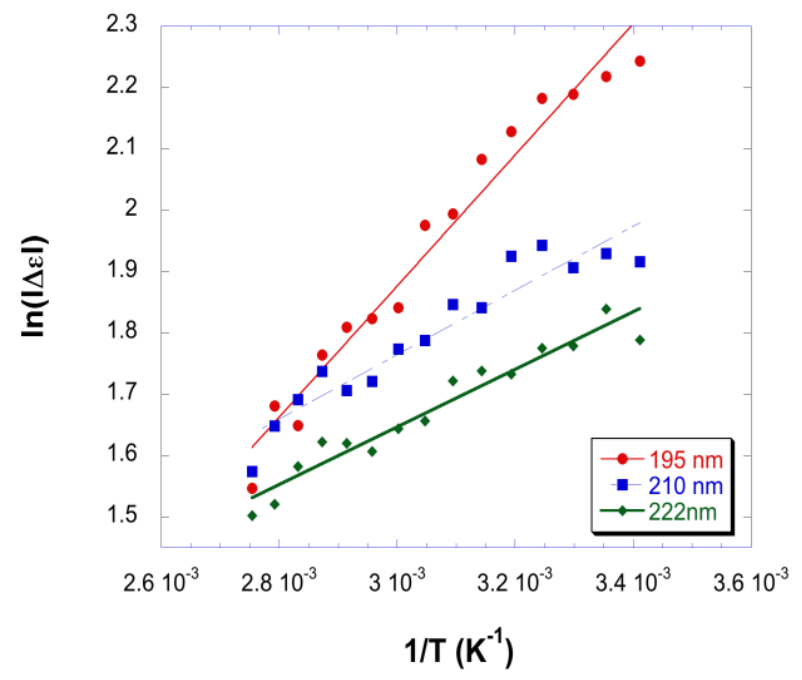


Figure 6
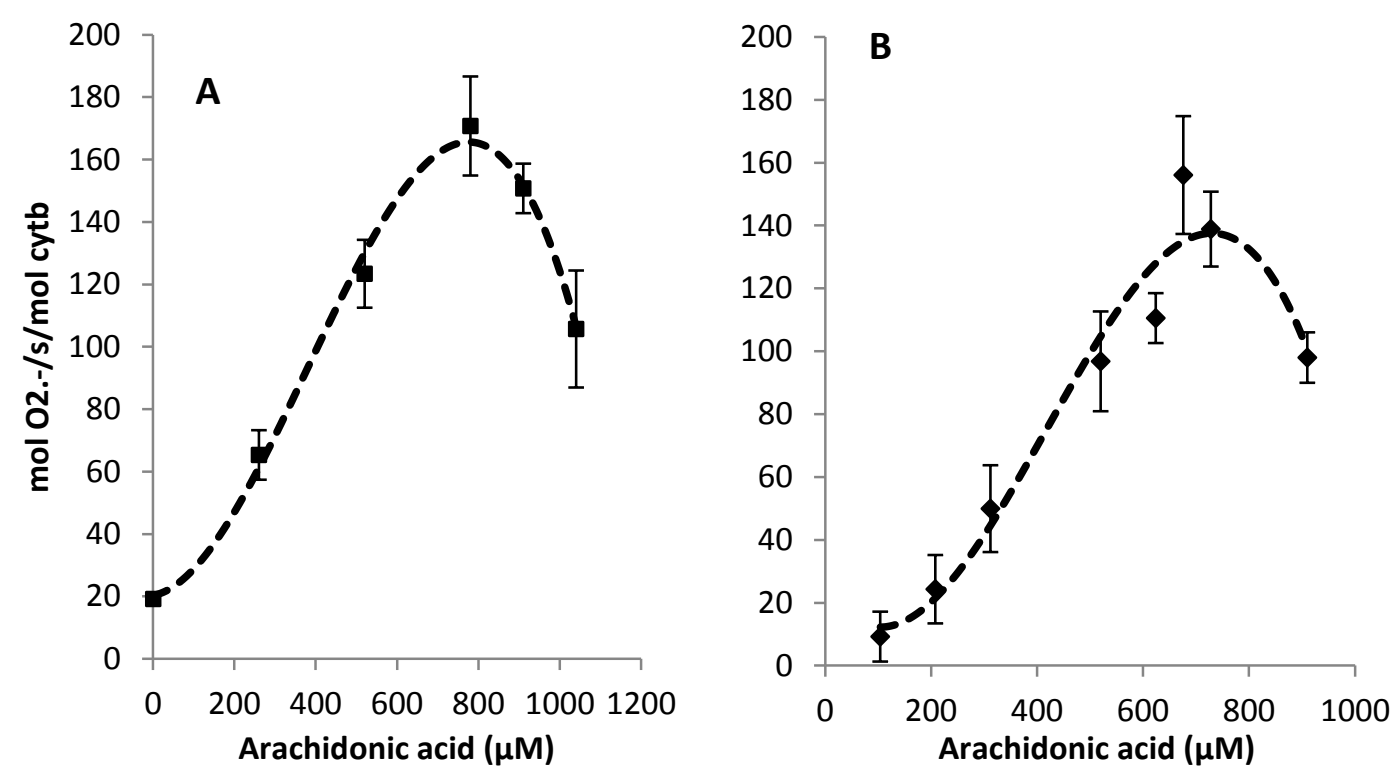
Figure 7
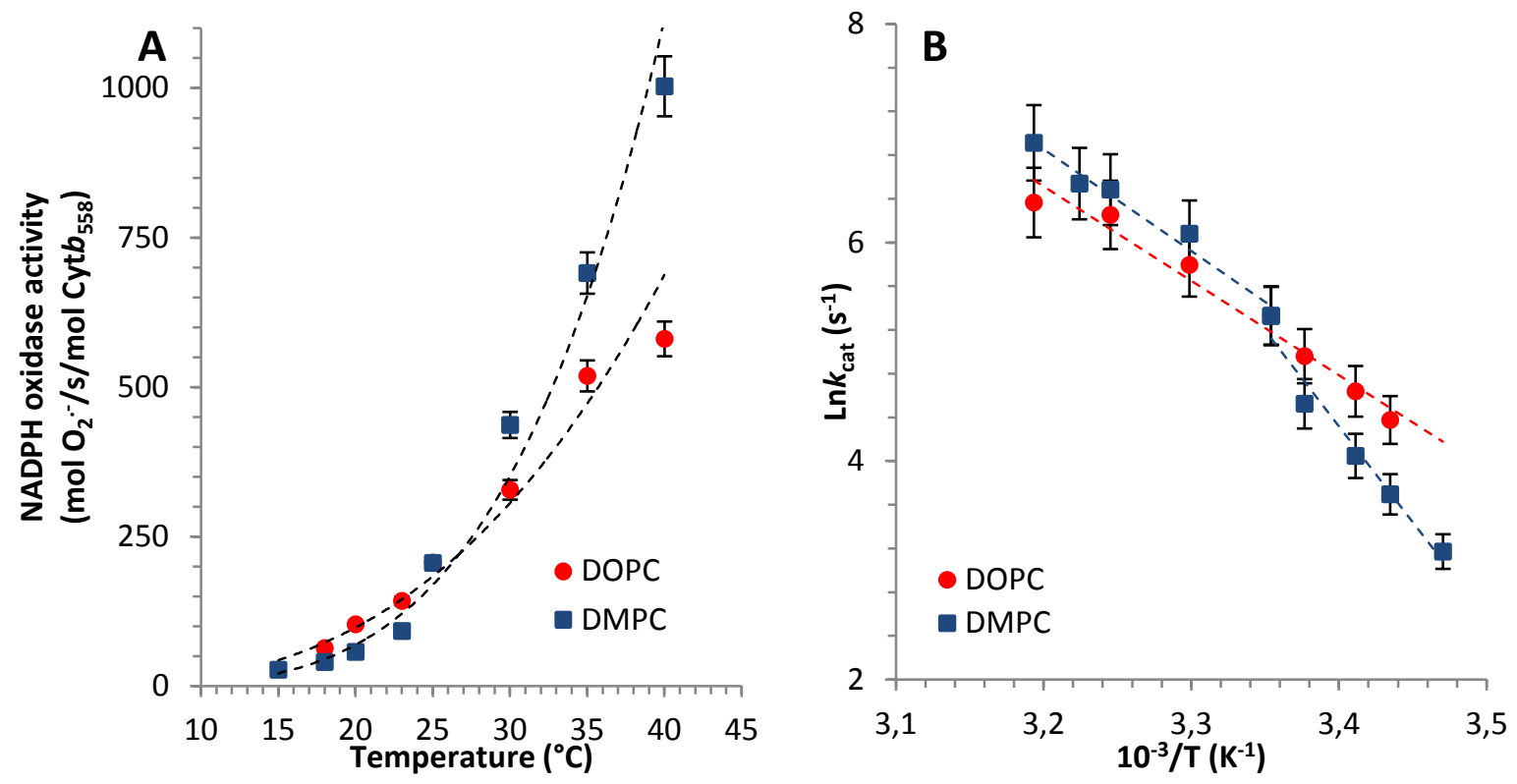
Figure 8
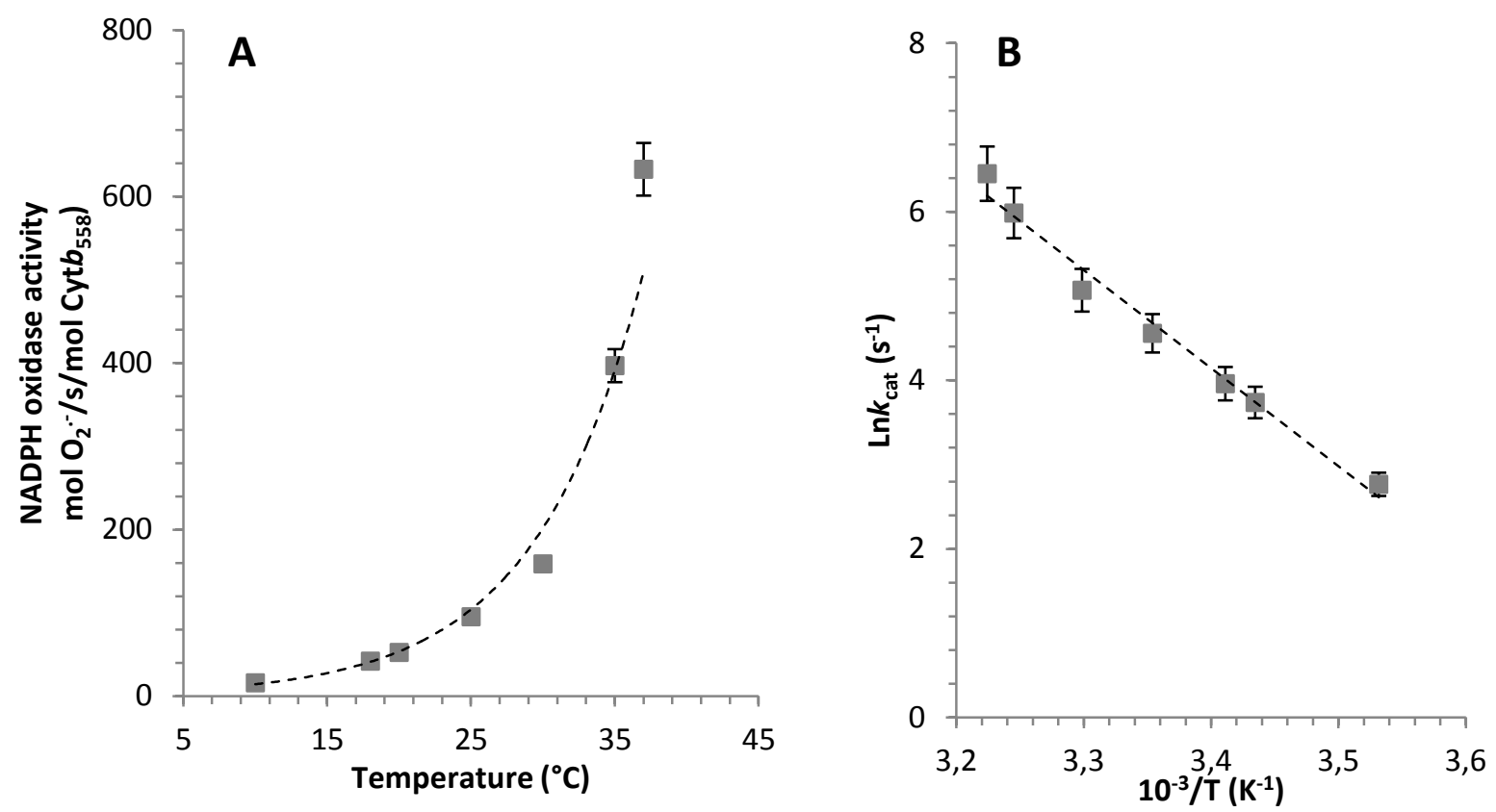
Scheme 1:

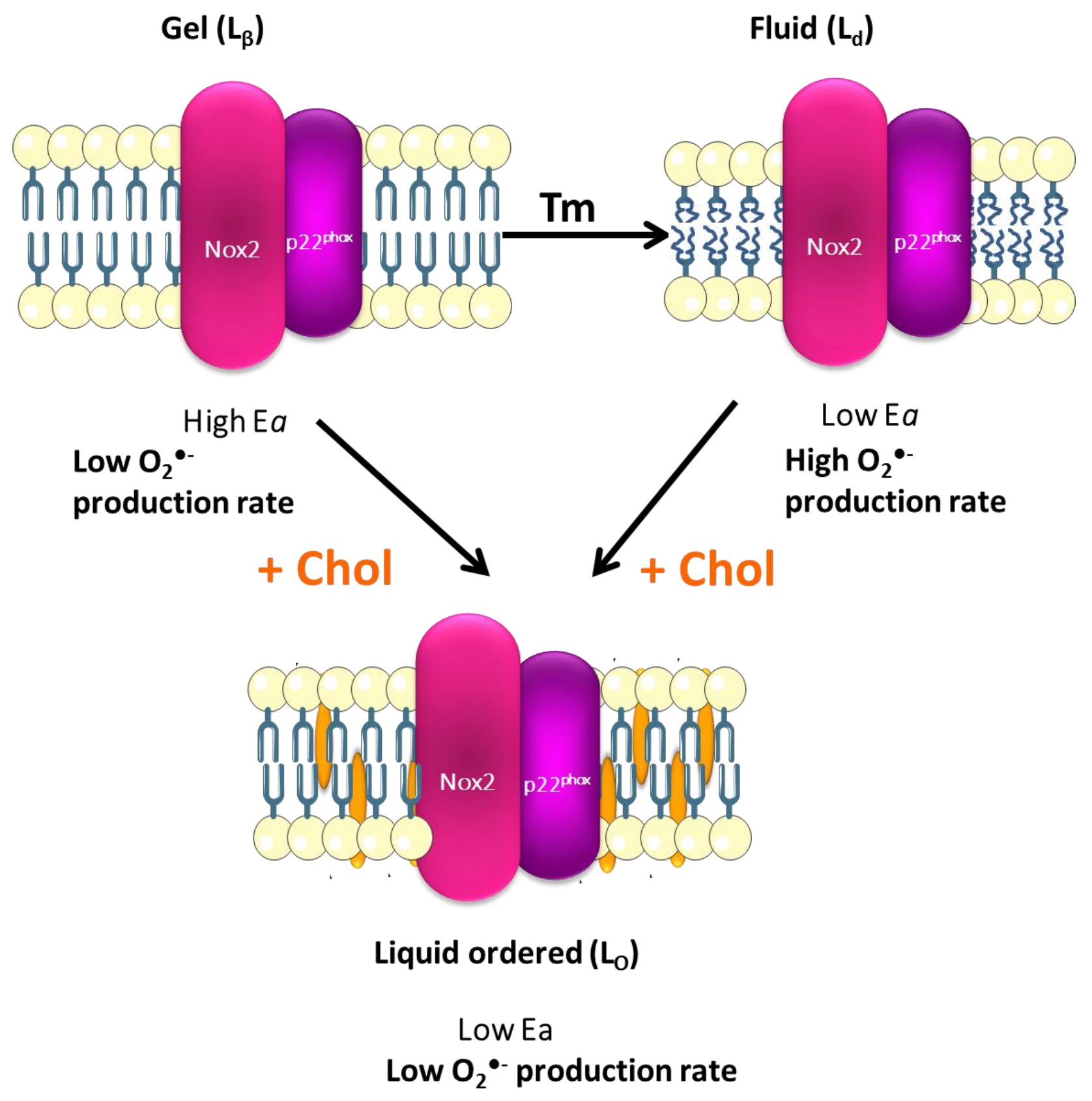


Figure S1: Structures of cholesterol and ergosterol

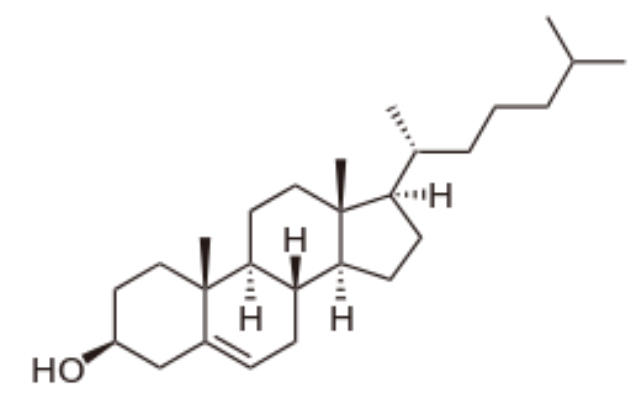

Cholesterol

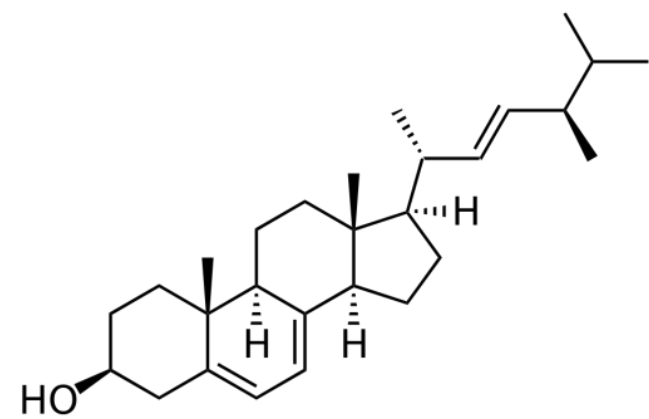

Ergosterol 